OECD Economics Department Working Papers No. 269

The Changing Health System in France

Stephane Jacobzone,

Patrick Lenain 


\section{Unclassified}

Organisation de Coopération et de Développement Economiques

Organisation for Economic Co-operation and Development

ECONOMICS DEPARTMENT
ECO/WKP(2000)42

OLIS : 27-Oct-2000

Dist. : 07-Nov-2000

English text only

Cancels \& replaces the same document: sent on OLIS 25-Oct-2000

THE CHANGING HEALTH SYSTEM IN FRANCE

ECONOMICS DEPARTMENT WORKING PAPERS NO. 269

by

Yukata Imai, Stéphane Jacobzone and Patrick Lenain

Most Economics Department Working Papers beginning with No. 144 are now available through OECD's Internet Web site at http://ww.oecd.org/eco/eco. 


\begin{abstract}
RÉSUMÉ
This paper reviews the performance of French health care system from an economic viewpoint. It also provides some policy recommendations. The health system in France is regarded as delivering highquality services, with freedom of choice and generally no waiting lists for treatments. Access to medical services is equal among the population and, unlike in some other countries, people can get the treatments they need irrespective of their social status or work situation. It is therefore not surprising that the French population is relatively satisfied with the health system. As this paper points out, however, this high quality comes at a price: health expenditure in relation to GDP is among the highest in the OECD and risks increasing further in the future in the absence of adequate measures. Past reform efforts, which have shifted the cost to the patient through higher out-of-pocket payments, have proved ineffective and raised equity questions. A new approach is therefore necessary. This paper argues that the renewed reform effort should provide microeconomic incentives to alter both the consumption and prescription behaviour. A package of measures tailored to the particular institutional and social characteristics of the French system is proposed, which would reign in costs while preserving the main strengths of the system-quality of care, freedom of choice, and equity of access.
\end{abstract}

JEL classification: I10, I18

Keywords: Health, France

******

Le présent document examine la performance du système de santé de la France, d'un point de vue économique. Il propose également des recommandations pour les réformes futures. Le système de santé français est considéré comme capable de fournir des services médicaux de qualité, avec une liberté de choix pour les patients et, en règle générale, sans liste d'attente pour les traitements. Les soins de santé sont distribués de façon équitable au sein de la population et, contrairement à d'autres pays, les patients peuvent obtenir des traitements médicaux quelque soit leur statut social ou professionnel. Il n'est donc pas surprenant que les français soient relativement satisfaits de leur système de santé. Néanmoins, comme souligné dans le présent document, la qualité des services médicaux a un prix : les dépenses de santé en relation au PIB sont parmi les plus élevées de l'OCDE et elles risquent de s'accroître davantage à l'avenir en l'absence de mesures adéquates. Dans le passé, les réformes ont visé à transférer une partie du coût des soins aux patients, mais ces efforts n'ont pas obtenu les résultats escomptés et ont remis en cause l'équité du système. Une nouvelle orientation est donc nécessaire. Ce document recommande de faire porter l'effort à l'avenir sur les incitations micro-économiques, afin de modifier les comportements de consommation et de prescription. Un ensemble de mesures adaptées aux caractéristiques institutionnelles et sociales de la France est proposé. Ces mesures devraient permettre de freiner les dépenses tout en préservant les atouts du système, c'est à dire la qualité des soins, la liberté de choix, et l'égalité dans l'accès.

Classification JEL : I10, I18

Mots-clés : santé, France

Copyright OECD, 2000

Applications for permissions to reproduce or translate all, or part of, this material should be made to: Head of Publications Service, OECD, 2 rue André Pascal, 75775 Paris Cedex 16, France. 


\section{TABLE OF CONTENTS}

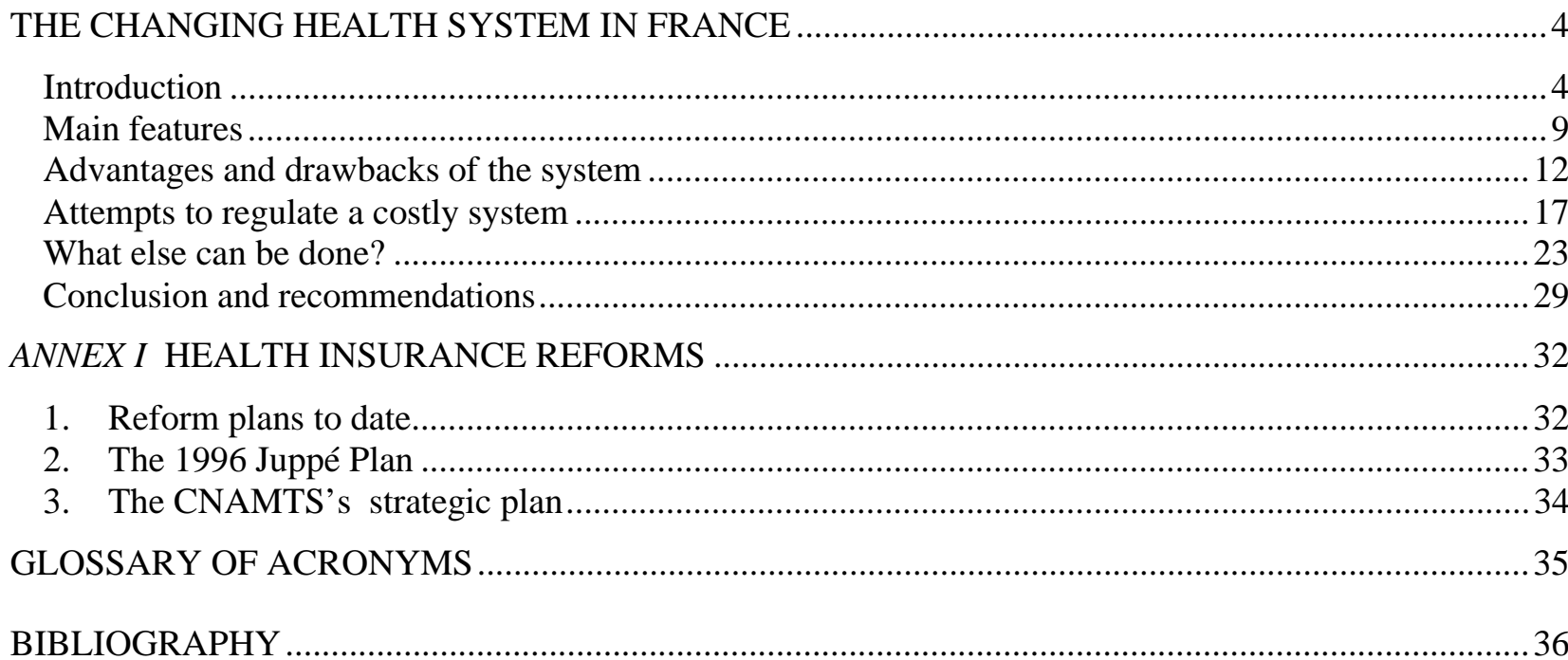

\section{Boxes}

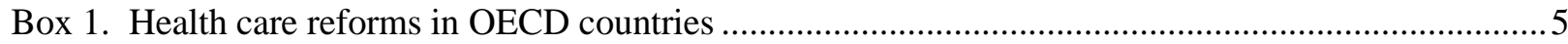

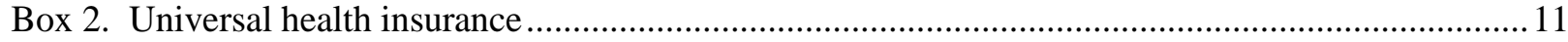

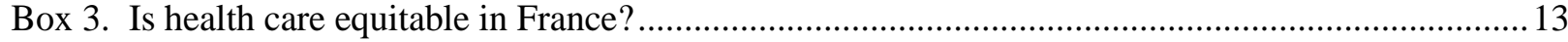

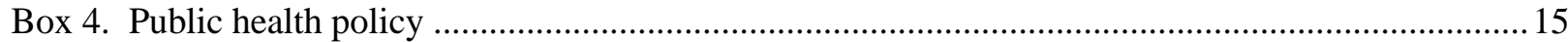

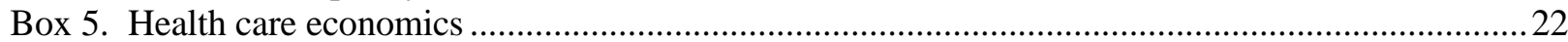

\section{Tables}

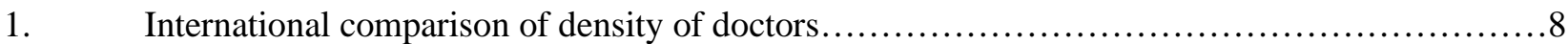

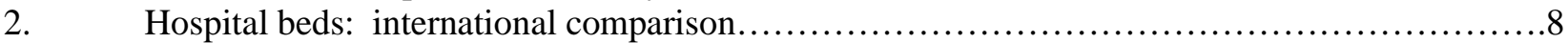

3. Health insurance spending targets and outturns........................................

\section{Figures}

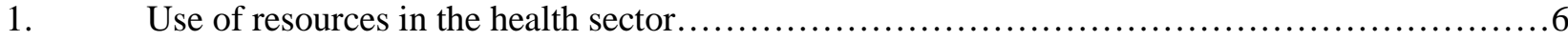

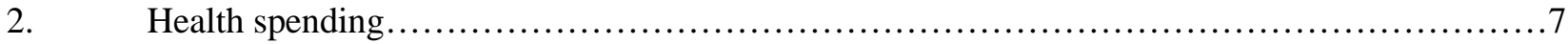

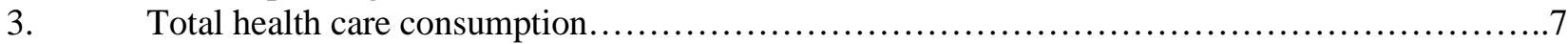

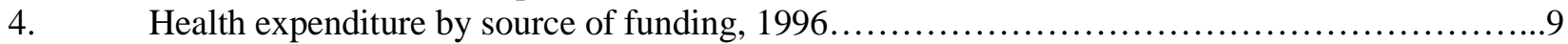

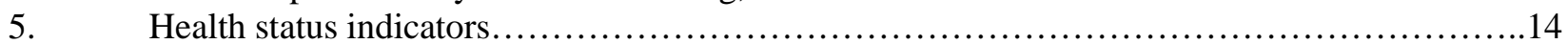

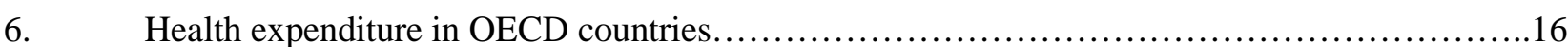

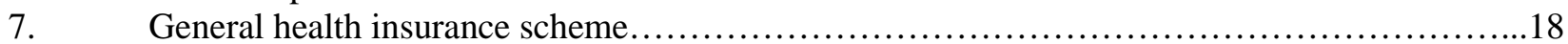

8. Relative trend of health care expenditure and national income................................

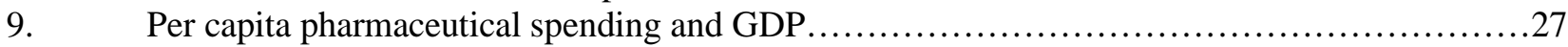




\title{
THE CHANGING HEALTH SYSTEM IN FRANCE
}

\author{
Yukata Imai, Stéphane Jacobzone and Patrick Lenain ${ }^{1}$
}

\section{Introduction}

1. In many respects, France has a health care system that other OECD countries might envy: the health status of the population ranks among the best in the industrialised countries; health spending is reimbursed generously; patients have a large freedom of choice amongst health care providers; patients generally do not have to queue for treatment; and a large amount of resources is allocated to health care by international standards (Figure 1). The system is expensive, however, and consumed a growing proportion of national income up until the mid-1990s (Figure 2). Upward pressure is exerted on spending by the use of expensive technology as well as by the freedom of choice enshrined in the French system that allows patients to consume as much as they want, and health care professionals to prescribe freely. This freedom of action, in a context of partial budget constraints, has led to an allocation of resources that is probably not optimal. An economic assessment of the performance of the system is thus necessary. This analysis is all the more important because, in the future, population ageing will be accompanied with growing health care needs.

2. Efforts to slow the growth of health spending have been intensified since the early 1990s (Annex I) like in other countries (see Box 1). In particular, a comprehensive programme has been under way since 1996 to bring spending under tighter control. Up to now these measures have had a real but limited impact on the overall rise in spending. Initiatives to modify incentives and behaviour have either been insufficient or slow in their implementation. A new impetus is needed to complete the efforts to date, while safeguarding the major strengths of the French system: quality of care, freedom of choice and equity of access.

1. An earlier version of this paper served as input into the 2000 OECD Economic Survey of France which was published in July 2000 under the authority of the Economic and Development Review Committee. The authors would like to acknowledge the assistance of the French authorities, especially from the Direction de la Prévision and other directorates of the Ministry of Economy, Finance and Industry in the preparation of this paper. They also especially acknowledge the assistance from the Directorate for Research, Economic Studies, Evaluation and Statistics (DREES), the Directorate for Social Security (DSS) as well as numerous other officials from the Ministry of Employment and Solidarity, and various health and public sector bodies, including the national health insurance fund, (CNAMTS), the Cour des Comptes and CREDES. Special thanks go to Howard Oxley who provided generous support and insightful comments. Without implicating them, this paper benefited from comments of Andrew Dean, Andrew Devlin, Jorgen Elmeskov, Mike Feiner, Jeremy Hurst, Val Koromzay, Gaetan Lafortune and Peter Scherer. Special thanks go to Roselyne Jamin for technical assistance and to Nadine Dufour and Doris Schombs for secretarial assistance. 
3. This paper begins by discussing the key features of the French health care system. It then evaluates past reform efforts and, in particular, the effectiveness of the macroeconomic spending control measures that have been implemented. After analysing the microeconomic aspects of the system, and especially agents' behaviour, it concludes with a set of recommendations.

\section{Box 1. Health care reforms in OECD countries}

Countries in the OECD area have reformed their health care systems in the last twenty years. Reviews of these reforms have been carried out across countries (see OECD, 1995) as well as for individual countries (see Girouard and Imai (2000), Koen (2000), and Orosz and Burns (2000) for recent examples). Obviously, countries have different types of health care systems, and therefore have different challenges to address. Nonetheless, there are common features in these reforms, which can be regrouped in three main categories.

- First, countries have aimed at bringing health care spending more into line with available resources. With economic growth slowing down in the 1980s and 1990s from the vigorous post second world-war expansion, health care spending had tended to "consume" a growing share of GDP. Countries have therefore taken steps to keep medical spending within reasonable limits, while continuing to provide the type of high quality services required by the population.

- The second goal of these reforms has been to make the health care systems more equitable. It is generally acknowledged that health care needs to be provided equally, and that there are positive externalities stemming from the provision of a minimum package of health care services to the entire population. For instance, maintaining minimum health standards for the entire population helps contain the risk of spreading contagion. Nonetheless, in some countries, access to health care remains unequal, which aggravates existing poverty problems.

- A third objective has been to improve both efficiency and quality of service provision through microeconomic reforms in the health care sector. Types of reform differ across countries. Where the lack of competition among health care providers is considered to be the source of inefficiency, measures have been taken to expose them to competitive pressures. On the other hand, where over provision of services is the problem, steps have been taken to alter incentives for providers, for example, by changing the payment method.

These reforms have had a varying degree of success. Although it is difficult to measure the performance of the health care sector, it is noteworthy that health indicators have generally improved in the OECD area. Remarkable progress has also been made in stabilising or lowering the share of health spending in GDP.

Health care reform is nonetheless an ongoing process. In some countries, a significant share of the population is still uninsured and therefore has a limited access to medical services. In other countries, overconstrained or inefficient delivery of healthcare services remains a major concern. There, services are rationed, patients' choice of physicians is restricted, and the population is unhappy with the system. In yet other countries, equity is not a problem and patients' satisfaction is relatively high, but the system is perceived to be too costly. Finally, many of these problems can only be aggravated by the ageing of population. Overall, health care reforms remain very much on the policy agenda for the future. 
Figure 1. Use of resources in the health sector $1996^{1}$

A. Hospital care ${ }^{2}$

Beds/1 000 inhabitants

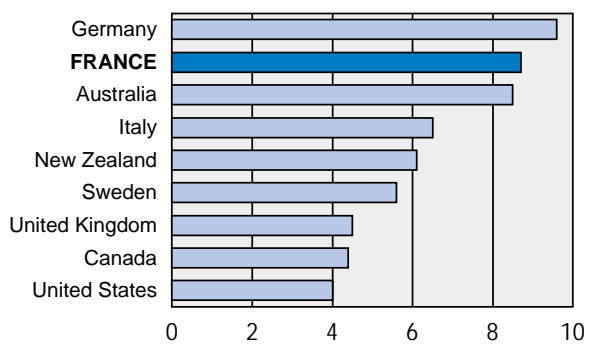

C. Hospital admissions $\mathbf{s}^{2,3}$ In per cent of the population

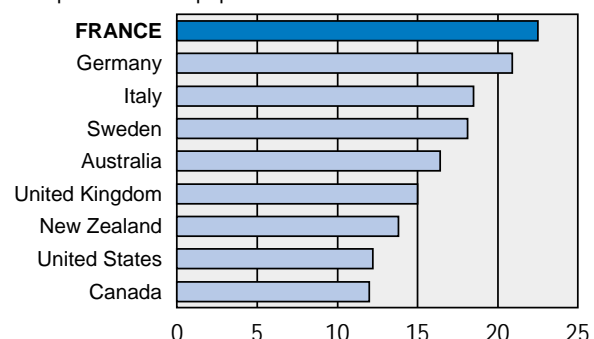

E. Doctors' consultations ${ }^{5}$ Number per capita

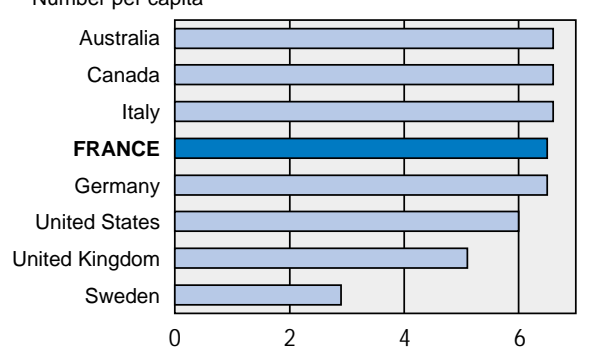

B. Average length of hospital stays ${ }^{2}$ Days

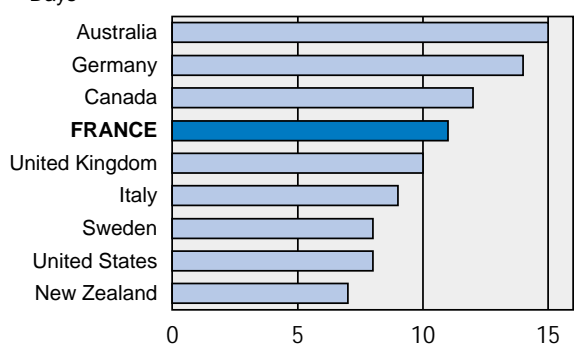

D. Practising doctors ${ }^{4}$

Density per 1000 inhabitants

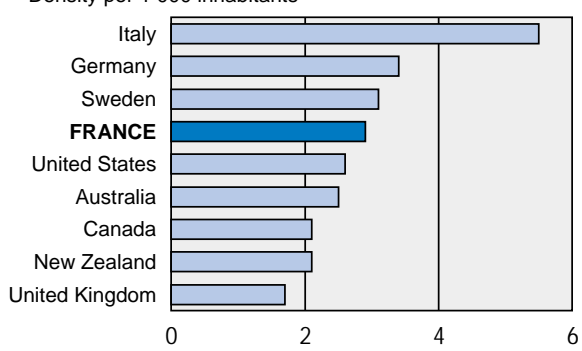

F. Total sales of pharmaceutical articles Per capita, in US\$ PPA

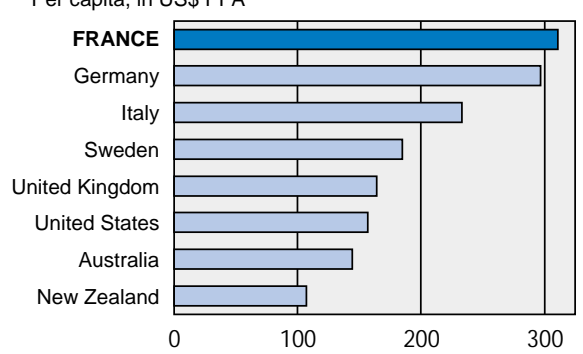

1. Or latest available data.

2. Including other institutions providing health care or hospitalisation.

3. Data for the United Kingdom cover only England, and have been adjusted on an ad hoc basis to allow a better comparison with other OECD countries.

4. For most countries, including also doctors with non-medical activities such as research, teaching and administration. 5. Data for Sweden exclude post-natal consultations in clinics.

Source: OECD, Health Data 99. 
Figure 2. Health spending

In per cent of GDP

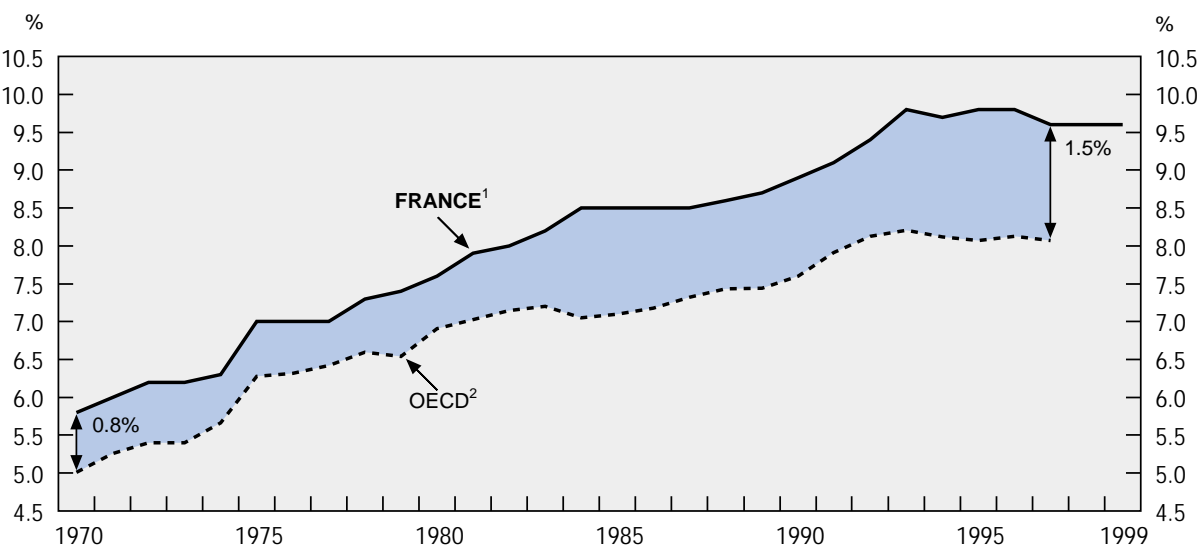

1. For 1998 and 1999 , data have been updated by the OECD.

2. Simple average for all OECD countries, excluding Greece, Hungary, Mexico, Poland and the Czech Republic. Source: OECD, Health Data 99.

Figure 3. Total health care consumption 1998

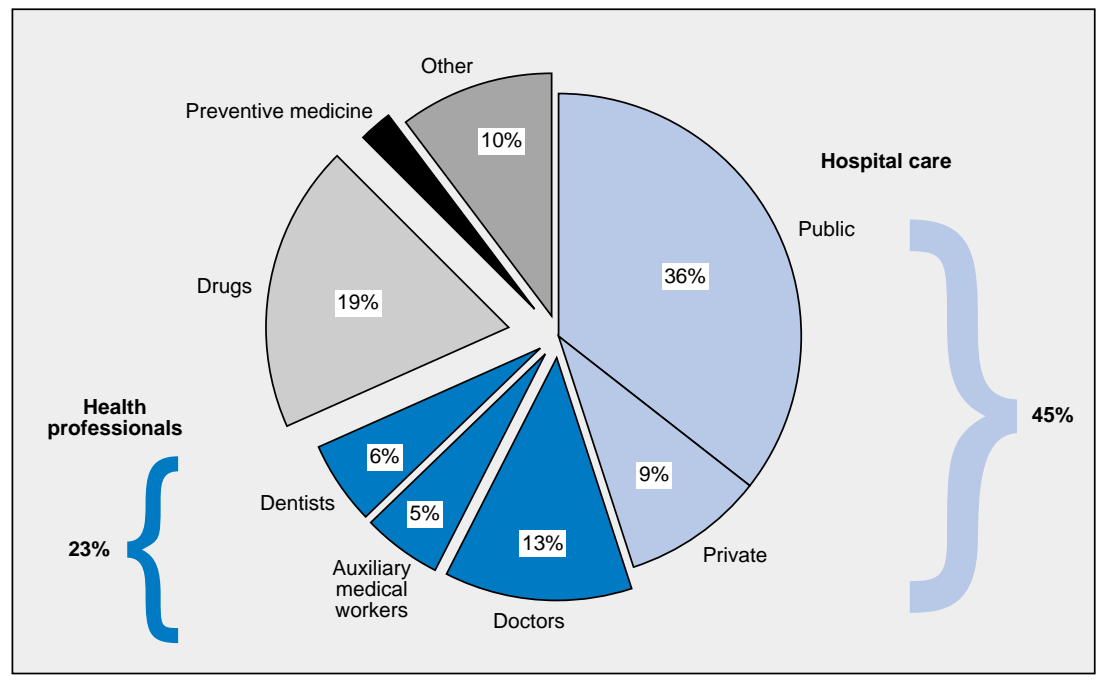

Source: Ministry of Employment and Solidarity, National health accounts. 
Table 1. International comparison of density of doctors

\begin{tabular}{|c|c|c|c|c|}
\hline & \multicolumn{2}{|c|}{$\begin{array}{c}\text { Total density of doctors } \\
\text { per } \\
1000 \text { inhabitants }\end{array}$} & \multirow{2}{*}{$\begin{array}{l}\text { Average } \\
\text { annual } \\
\text { percentage } \\
\text { change }\end{array}$} & \multirow{2}{*}{$\begin{array}{c}\text { Share of } \\
\text { specialists } \\
\text { in per cent } \\
1997\end{array}$} \\
\hline & 1980 & 1997 & & \\
\hline Italy $^{1}$ & 2.6 & 5.8 & 4.8 & $35^{4}$ \\
\hline Germany & 2.3 & 3.4 & 2.3 & 68 \\
\hline Belgium & 2.3 & $3.4^{3}$ & 2.5 & $51^{3}$ \\
\hline France & 2.0 & 3.0 & 2.4 & 50 \\
\hline United States & 2.0 & 2.7 & 1.8 & 66 \\
\hline Netherlands & 1.9 & 2.6 & 2.9 & $68^{2}$ \\
\hline Canada & 1.8 & 2.1 & 0.9 & 49 \\
\hline Japan & 1.3 & $1.8^{2}$ & 1.9 & n.a. \\
\hline United Kingdom & 1.3 & $1.7^{2}$ & 1.6 & n.a. \\
\hline
\end{tabular}

1. For these countries, the densities correspond to the number of doctors trained and not necessarily to the number of doctors practising.

2. 1996

3. 1995 .

4. 1994.

Source: OECD, Health Data 99.

Table 2. Hospital beds: international comparison

\begin{tabular}{|c|c|c|c|c|c|c|c|}
\hline & $\begin{array}{l}\text { Num } \\
\text { per } 10\end{array}$ & $\begin{array}{l}\text { beds }{ }^{1} \\
\text { bitants }\end{array}$ & Total c & cy rate & $\begin{array}{r}\text { Sho } \\
\text { per } 10\end{array}$ & $\begin{array}{l}\text { beds } \\
\text { bitants }\end{array}$ & $\begin{array}{c}\text { ALOS }^{2} \\
\text { Average } \\
\text { length of } \\
\text { stay, } \\
\text { short-stay } \\
\text { beds }\end{array}$ \\
\hline & 1980 & 1997 & 1980 & 1997 & 1980 & 1997 & 1997 \\
\hline United States & 6.0 & 4.0 & 77.7 & $66.0^{4}$ & 4.4 & $3.3^{3}$ & $6^{3}$ \\
\hline Canada & 6.7 & $4.2^{3}$ & 82.8 & $84.2^{6}$ & 4.6 & $3.6^{6}$ & $8^{3}$ \\
\hline United Kingdom & 8.1 & 4.3 & 81.4 & $80.0^{5}$ & 2.9 & 2.0 & $5^{3}$ \\
\hline Belgium & 9.4 & $7.2^{3}$ & 85.7 & $83.6^{4}$ & 5.5 & $5.3^{4}$ & $8^{3}$ \\
\hline Italy & 9.7 & $6.5^{3}$ & 68.9 & $73.4^{3}$ & 7.6 & $5.5^{3}$ & $8^{3}$ \\
\hline France & 11.1 & 8.5 & 81.1 & 81.9 & 6.2 & 4.3 & 6 \\
\hline Germany & 11.5 & 9.4 & 84.9 & 76.2 & 7.7 & 6.6 & 10 \\
\hline Netherlands & 12.3 & 11.5 & 90.9 & 87.7 & 5.2 & 3.8 & 9 \\
\hline Japan & 13.8 & 16.4 & 83.3 & 83.9 & n.a. & n.a. & n.a. \\
\hline
\end{tabular}

1. These data should be treated with caution. In some countries, a relatively large share of beds may in fact correspond to beds for institutionalised old people. Thus, the figures for Japan and, to a lesser extent, those for the Netherlands, are not entirely comparable with the other countries. A comparison of solely short-stay beds is more relevant but cannot be done for Japan.

2. ALOS = average length of stay (number of days).

3. 1996 data.

4. 1995 data.

5. 1994 data.

6. 1993 data.

Source: OECD, Health Data 99. 
Figure 4. Health expenditure by source of funding, 1996

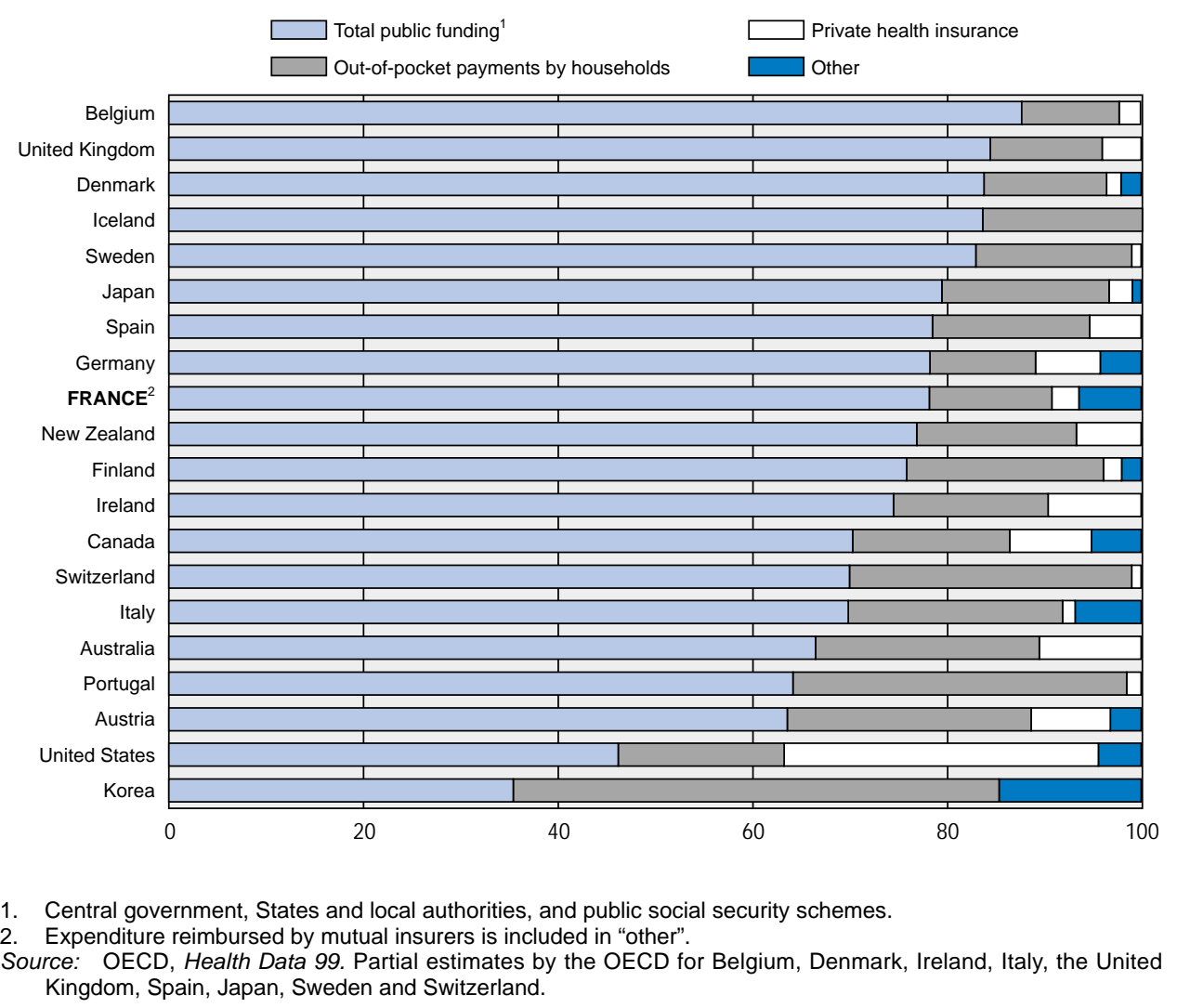

2. Expenditure reimbursed by mutual insurers is included in "other".

\section{Main features}

4. The French health care system can be characterised as a mixed system combining elements of private and public care, as well as publicly funded and private health insurance elements. Slightly less than half of care is provided by public hospitals and private clinics, the remainder by private service providers (ambulatory doctors, auxiliary medical staff, drugs) (Figure 3, Tables 1 and 2). Almost 80 per cent of total health spending is publicly funded, about 10 per cent is paid for by mutual insurers (mutuelles) and private insurers, and the remainder is paid for directly by patients (Figure 4).

\section{A two-tier health insurance system}

5. The health insurance system has two tiers: a basic mandatory public pillar, and supplementary insurance provided by private insurers and mutuelles. The basic scheme covers the entire resident population: workers and their families are affiliated with public health insurance funds ${ }^{2}$, while solidarity

2. There are 18 basic health insurance funds. The main one, the Caisse Nationale d'Assurance Maladie des Travailleurs salariés (CNAMTS) covers four-fifths of the population, mostly private sector employees and their families. Other important schemes are the Mutualite Sociale Agricole (for farmers) and the Caisse Nationale d'Assurance Maladie des Travailleurs Indépendants et Artisans (CANAM). There are also special statutory funds for certain public sector employees and for miners. These funds administer benefits. Health insurance contributions are paid by employers and employees (mainly via the contribution sociale généralisée). The contributions are collected by separate agencies in charge of collecting all social contributions.. 
arrangements ensure that persons who are excluded from normal cover, because they are not in stable employment or are in a transitional situation, are also covered.

6. Doctors are paid directly by patients. Even though it is growing slowly, the direct payment to doctors by the health insurance funds (the so-called "tiers payant" system) concerns only a small fraction of health professionals. Patients generally receive a partial reimbursement of their expenditure by the health insurance funds, which leave a co-payment to be paid out of their pocket (ticket modérateur).

7. Supplementary insurance has expanded greatly over the past decades and now covers over 80 per cent of the population ${ }^{3}$. Supplementary insurance schemes generally refund the full ticket modérateur of the basic scheme, thus cancelling out its moderating effect on consumption. In addition, subsidiary mechanisms enable the public schemes to increase their cover to 100 per cent for some categories of patients and diseases (long-term disabling illness, invalidity pensioners, those with universal medical insurance). The combination of these arrangements means that, for most of the population, health care expenditure is largely refunded. This, together with a diversified supply of medical services -- often on a fee-for-service basis -- has been one of the factors responsible for the rapid increase in health spending.

8. Underneath these broad characteristics, the organisation of the system is relatively complex. The State has an important role in managing the system. Three-quarters of beds are in public hospitals, which account for two-thirds of hospital spending, and public hospital staff have the status of civil servants. To offset the demographic imbalances between funds, resources are transferred from the main scheme and the local authority scheme to those for farmers, the railways (SNCF) and the miners.

\section{Various methods of financing}

9. Public hospitals are funded out of global budget appropriations which are set annually by the authorities and allocated every month by the health insurance funds. Modest payments by patients top up these budget appropriations. Up to now, the appropriations have been set on the basis of the historic operating costs of hospitals, with a modest allowance made for their actual level of activity, the average case-mix, and specific costs of treating certain diseases or expensive drugs.

10. Private clinics are paid on a fee-for-service basis. Similarly, ambulatory care is provided primarily by doctors in private practice on a fee-for-service basis. The authorities set official schedules of reimbursement which in a number of cases correspond to the actual prices imposed on service providers ${ }^{4}$. The prices of reimbursable drugs and most other medical goods such as prostheses are set by the government after consulting committees of experts and in the light of the evaluations provided by private suppliers and pharmaceutical companies.

3. Supplementary insurance is provided by mutuelles subject to a special code and taxation, and by traditional insurance companies. In the private sector, the bulk of this insurance is bought in the group insurance market by companies as part of job-related benefits.

4. About a quarter of ambulatory care doctors are allowed to charge more than the official schedules, normally because they have special qualifications. This so-called "sector II" was opened up at the start of the 1980s but the qualification requirements were tightened up considerably, and to a large extent the sector has been closed to further access by the 1990 agreement between the doctors and the authorities (convention). Its relative share declined from 31 per cent in 1990 to 27 per cent in 1997, but the share for specialists is higher -- 34 per cent. Fees of sector II doctors, which are beyond the official fee schedules, are reimbursed only by the better supplementary insurance schemes, and then the amount varies quite widely from one scheme to another. 


\section{A plentiful supply of ambulatory care}

11. The system of ambulatory care provides easy access to a specialist, in contrast with the situation in many other OECD countries, where a patient can consult a specialist only through an out-patient consultation in a hospital, often with long waiting lists. One of the consequences of this environment is competition between specialists and general practitioners as well as over-supply in some specialities. As a result, in practice, some specialists work as general practitioners, which adds additional necessary costs. Specialists with imaging equipment may also have an incentive to over-prescribe.

\section{Efforts to ensure greater social and geographical equity}

12. In order to ensure greater equity of access to health care, universal health insurance (couverture médicale universelle or CMU) is available since 1 January 2000 to the neediest members of society, a replacement of the former medical allowance dispensed by local authorities (see Box 2). The first part of CMU provides basic cover to all those residing lawfully in France, irrespective of their employment situation or insurance contribution record. In practice, people formerly without health insurance, such as those not in stable employment or those facing complex administrative problems, as in the case of foreigners waiting to get official residency papers, are now covered. The second part -- and the most important in quantitative terms -- provides free supplementary cover to people whose income is under FF 3500 per month per person ${ }^{5}$. The government estimates the ultimate possible number of beneficiaries at some six million, half of them being made up of recipients of the guaranteed minimum income (RMI) and members of their families.

\section{Box 2. Universal health insurance}

The main features of universal health insurance (CMU) are:

- The ticket modérateur does not have to be paid by the patient, so that medical goods and care are completely free up to the limits set by the government. Certain types of expenditure (optical and dental care) are capped.

- Patients do not have to pay fees up front; this is the so-called third-party billing ("tiers payant") system, whereby the health insurance funds pay health professionals and institutions directly.

- One-stop processing of benefits: in contrast with the previous system, under which beneficiaries and entitlements were determined by several offices, the CNAMTS offices now do it alone; entitlement is immediate once it has been determined.

- Automatic entitlement: the government decided that coverage cannot be refused because information is missing. Nearly 3 million people who used to receive free medical assistance from the local authorities (départements) or those who receive the guaranteed minimum income (RMI) are automatically entitled to CMU without having to apply for it.

- Free choice of the supplementary cover provider (health insurance fund, mutuelle, private insurer). The CNAMTS is still the institution of last resort. In case of an affiliation with a mutuelle or a private insurer, these receive a subsidy of FF 1500 per year per affiliated person, to meet the costs of supplementary cover.

5. The income ceiling is degressive: FF 3500 per month per person, FF 5250 for two people, FF 6300 for three people, FF 7350 for four people, and FF 1400 for each additional person after that. Some social benefits are not 
13. Even so, inequalities remain (see Box 3). Households, whose incomes are too low to allow them to contribute to a supplementary insurance scheme, but too high for them to qualify them for universal health insurance, have to pay for a substantial part of their health care themselves, in particular services which are poorly refunded such as dental and optical care. And it can be a problem for them to have to put up the money in advance (Dourgnon and Grignon, 2000). Also, access to certain types of care is relatively expensive, given that a quarter of the medical profession in the ambulatory sector is free to charge the fees it wants and that the supplementary insurance schemes refund only a small part of the costs of private beds and treatment by hospital doctors.

14. There are also instances of inequity at the geographical level. Differing arrangements contribute to inequalities of care access between regions and even within regions. In a context of freedom of establishment, there are wide disparities in ambulatory care supply, doctor density being highest in Ile de France and the Mediterranean region. Where hospitals are concerned, despite centralised decision-making procedures, there are big differences in resource allocation between regions, in terms of beds, hospital medical staff, heavy equipment and budget funds. In some localities, waits for treatment are considered to be excessive. The authorities have therefore embarked on a policy of progressive equalisation that should ultimately reduce these long-standing inequalities of allocation between regions and medical establishments. Furthermore, prior to the introduction of CMU, the arrangements applying to care access for the neediest (free medical assistance from the local authorities) gave rise to inequalities of treatment between départements. In this regard, CMU as an equitable nation-wide scheme represents a considerable step forward.

\section{Advantages and drawbacks of the system}

\section{The system is perceived as being satisfactory ...}

15. The population seems to be satisfied with the health care system. Surveys such as the Eurobarometer show that the opinion rating for the French system is relatively high, two-thirds of the population being fairly satisfied, compared with 40 per cent in the United Kingdom and 20 per cent in Italy (Mossialos, 1997). The population appears to be happy with a system that combines freedom of choice, no delay in service delivery and high quality of care delivered with a comparatively extensive use of modern medical technology and practice.

16. France also ranks high among OECD countries in terms of health and mortality indicators (Figure 5). For example, in 1997 female life expectancy at birth was second (82.3) after Japan (83.8). Female life expectancy at age 65 was also second for women, while male life expectancy was fourth in 1996. Old-age disability is on a marked downward trend, particularly for men, in line with trends in the United States and Japan (Jacobzone et al., 2000). The same is true for infantile mortality, which is very low, just above the very low levels in Scandinavian countries.

included in the calculation of resources (the allowance given at the start of the school year) while only a fixed part of other benefits received (family allowances, housing benefit) is taken into account.

6. For example, France has one of the highest rates of cardiac catheterization and angioplasty, close to those in Germany and Belgium at the European level (Jacobzone et al., 1997). 


\section{Box 3. Is health care equitable in France?}

Ensuring an equitable access to health care is a key policy issue in most OECD countries. Equity relates to the access not only of low-income groups, but also of persons living in different parts of national territories. There is a large academic literature, mainly on the former (Van Doorslaer et al., 1993). Nonetheless, improving access of low-income and isolated persons raises difficult implementation issues. Resolving these issues calls for clear statistical indicators, which are often unavailable. It also involves a change in resource allocation, which can be delicate politically. Thus, making health care equitable is an important policy objective, but one that requires continued attention.

\section{Health and income levels}

Despite some reductions in inequalities, key indicators show that health status in France remains uneven across income groups, as in other industrialised countries. For instance, low-skilled blue collar workers have a life expectancy of 8 to 35 years shorter than senior executives (Mormiche, 1997). Surveys also reveal wide differences in health care consumption by income and education groups. The lack of adequate health insurance, especially supplementary insurance, appears to restrict access to care for underprivileged groups. The introduction of the Couverture Médicale Universelle is a broad-brush attempt to reduce these constraints. Efforts have also been made to standardise contribution rates (with the CSG), which however remain far from uniform across schemes. A complex ex-post demographic compensation mechanism is used to adjust funding across health insurance schemes, which is not providing full risk equalisation. In addition, despite recent progress, copayments remain quite significant for ambulatory care. Beyond the standard doctor fee exists a wide array of above-standard fees (Secteur II) and unregulated fees (dépassement permanent, honoraires libres, tarif non conventionné), which makes access to quality care dependant on ability to pay. A similar phenomenon also occurs in public hospitals (clientèles privées).

\section{An unequal distribution of resources across the national territory}

Despite centralised decision-making and planning procedures, the distribution of resources on the national territory remains relatively uneven. This applies to both public hospitals and the private ambulatory care. For instance, financial allocations to the Centres Hospitaliers Universitaires - CHU (university hospitals) range from FF 559 per inhabitant (Poitou-Charentes) to FF 208 (Île de France). Regional disparities are widest for heavy equipment, though they are narrowing as the activity using such equipment spreads. Disparities are also wide for medical personnel in both public hospitals and private care, but are comparatively modest for non-medical hospital staff and the number of hospital beds.

Regional differences have not been reduced in the public hospital sector until recently, and have actually increased in the case of private ambulatory care. For instance, recourse to cataract surgery, caesarean birth, interventional cardiology and endoscopy varies widely from region to region, irrespective of the health status of the populations concerned. Hence, a mismatch between resource availability and morbidity prevails. Broadly speaking, resources are most generously granted to the metropolitan area of Ile de France and to southern France, while morbidity is higher in the Northern regions, and to a lesser extent, Alsace, Lorraine and Brittany. ${ }^{7}$

Policies for improving regional distribution of health care resources are a subject of thorough, though complex, debate (Mougeot, 1999; Cour des Comptes, 1999). The authorities have sought to reduce regional disparities not only in resource endowment, but also in performance of care providers. However, redistribution requires a shift in resources away from the most favoured regions, which may result in social tensions among affected personnel and pressures on elected local representatives. Efforts need to be continued nonetheless, and even broadened to include the ambulatory care sector.

7. Caution is needed in interpreting regional differences in morbidity, as factors extraneous to the health care system may play a key role. Epidemiological studies have shown that diet and the industrial context might play a role in explaining regional differences. 
Figure 5. Health status indicators

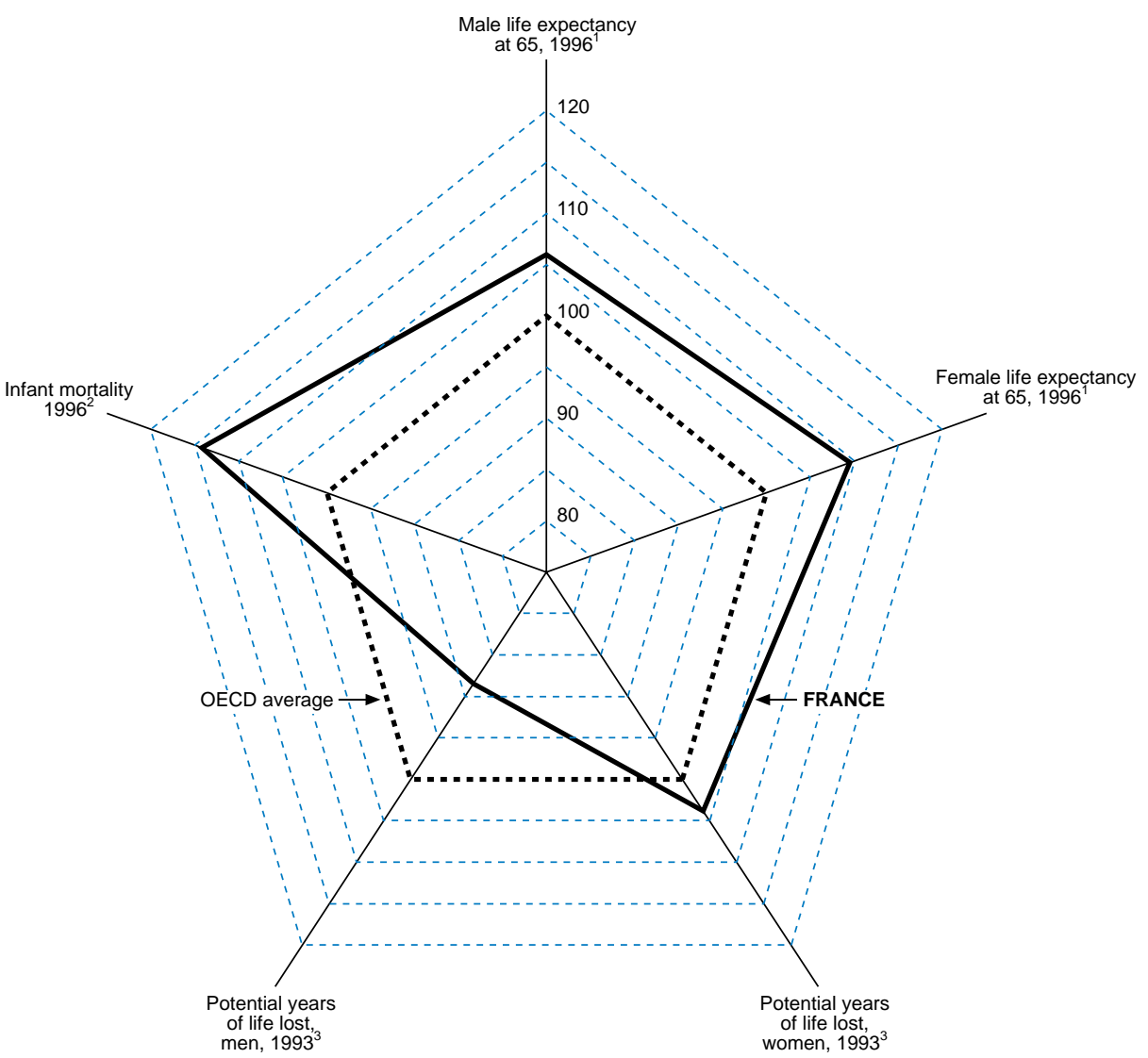

Note: An observation point higher than 100 for life expectancy means a higher life expectancy; an observation point higher than 100 for infant mortality means a lower mortality; an observation point higher than 100 for potential years of life lost means fewer years of life lost.

1. The OECD average does not include Korea, Ireland, Luxembourg and Turkey.

2. The OECD average does not include Korea, Mexico, Turkey, Hungary and Poland.

3. The OECD average does not include Belgium, Korea, Turkey, Mexico, Hungary and Poland

Source: OECD, Health Data 99. 
17. The high early mortality for men compared with the OECD average is nonetheless disquieting. Life expectancy at birth for men is, in consequence, relatively low. Reports on public health show, however, that this is due to factors which have little to do with the functioning of the health system proper and is caused by the high number of violent deaths from suicides and road accidents and an incidence of AIDS well above the European average and comparable to that of other Mediterranean countries such as Spain and Italy (Haut Comité de la Santé Publique, 1998; Ministry for Employment and Solidarity, 2000). Another example is a specific association of high tobacco and alcohol consumption, with its attendant consequences of a higher rate of cancer of the lung and of the upper respiratory and digestive systems. This shows the need for a broad-based, coherent approach to public health, which is beginning to emerge in the French decision-making system (see Box 4).

\section{... but the cost is high}

18. A health care system with which the population is very satisfied and which delivers efficient outcomes does not come cheap. It is, thus, not surprising that the French system is relatively expensive by international standards. The share of health expenditure in GDP rose from 7.6 per cent in 1980 to 8.9 per cent in 1990 and 9.6 per cent in 1997 and 1998. On this indicator, France ranks fourth in the world, behind the United States, Germany and Switzerland (Figure 6). On average, working households spend 20 per cent of their gross income on health, including supplementary insurance contributions. Given the weight of social contributions in the cost of labour, modifications have been made to the method of health financing, with, in particular, the introduction of a more broadly-based contribution in 1991, the contribution sociale généralisée, and its gradual extension in order to finance the health insurance schemes.

\section{Box 4. Public health policy}

Until lately French public health policy suffered from shortcomings that are only just starting to be addressed (Dab, 1997). This shortcoming has become more visible in recent years. There is a "burden of the past" in this area (Morelle, 1996). Public health has long occupied a minor place in the French decision-making and training system. A fully-fledged public health discipline during the internship part of medical studies was created only very recently. Teaching and research structures, though well developed, are still well behind those in Anglo-Saxon countries. A national body was set up in 1990 to co-ordinate public health policy (the Haut Comité de la Santé Publique). The role and functions of the École nationale de la Santé Publique have been expanded, but they are still very limited. Tools for monitoring public health have been strengthened, in particular by the creation of a disease monitoring centre (Institut de Veille sanitaire), which replaced the former National Public Health Network. Like the Atlanta Centre for Disease Control, this Institute makes it possible to keep an ongoing track of the epidemiological characteristics of diseases. Lastly, for the past ten years the government has been steadily creating independent agencies under the aegis of the Ministry of Health for drug evaluation, blood supply management, food safety, and medical accreditation and evaluation. Despite this progress, France still does not have an explicit health policy with global health objectives and measures to achieve a better balance between prevention and care. 
Figure 6. Health expenditure in OECD countries

In per cent of GDP

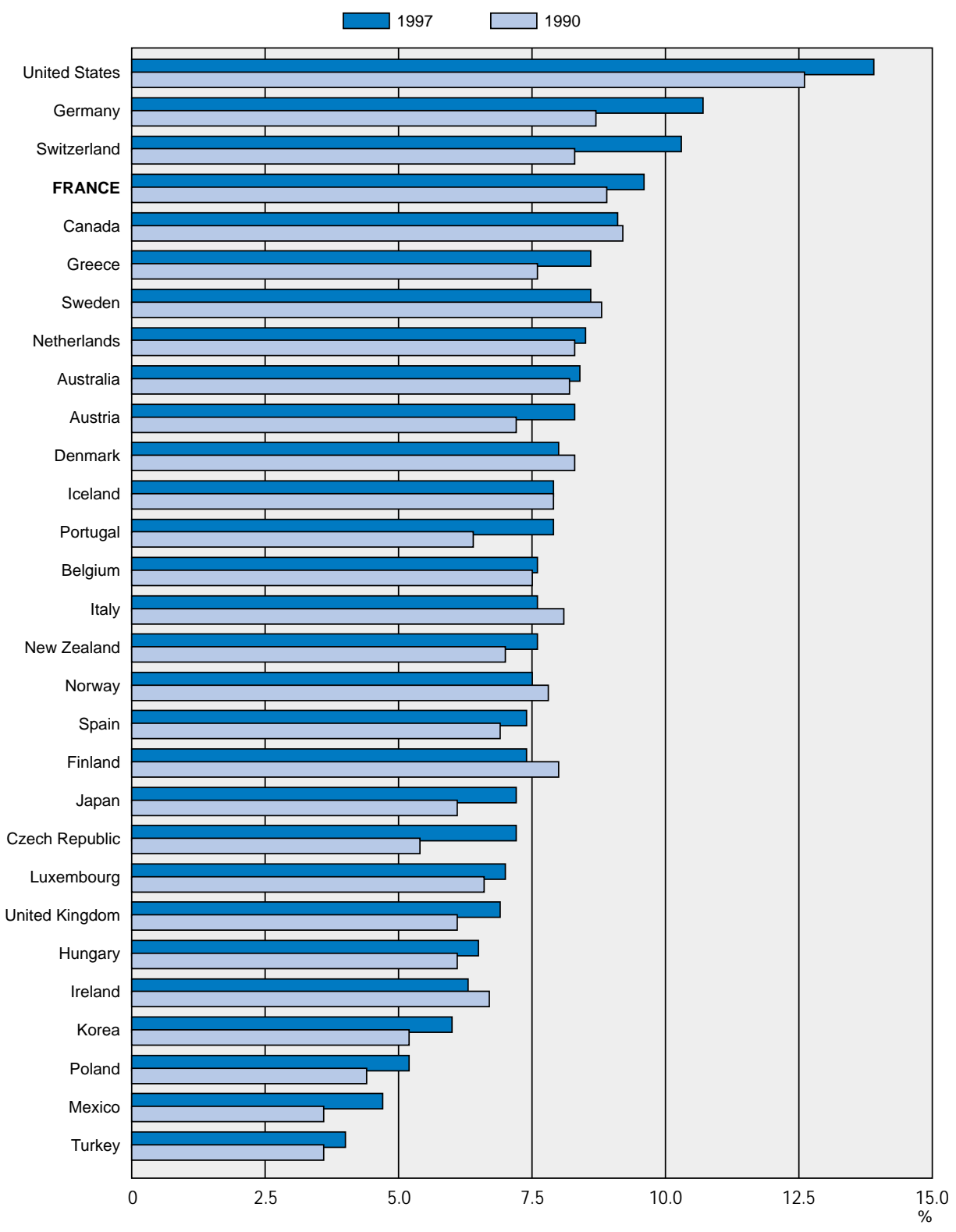

Source: OECD, Health Data 99. 


\section{Attempts to regulate a costly system}

\section{From covering deficits to the gradual introduction of a financial constraint}

19. With health expenditure rising more steeply than receipts, the financial situation of the health insurance funds worsened steadily during the 1980s and the early 1990s. The gap between spending growth and the resources available prompted governments to implement a series of stabilisation plans. Up to the mid-1990s, the reforms implemented in response to burgeoning expenditure relied largely on shortterm consolidation measures to try and balance the health insurance accounts. What they had in common was that they sought to cover ex post the deficits of the health insurance funds by increasing revenue while raising patients' contributions in the form of higher co-payments. The only true economic constraint, until the early 1990s, was the global budget system for public hospitals introduced at the time of the budget tightening in 1983-84. In the ambulatory sector, the authorities curbed the growth of the fee schedule and drug prices, and reduced reimbursement rates.

20. These measures had, however, only a modest, short-term effect. Health professionals responded to the controls on their prices by increasing volume so as to prevent the erosion of their incomes. Despite their growing numbers, and against a background of economic restraint, general practitioners were able to maintain the level of their fee income in real terms between 1985 and 1995 (Beudaert, 1999). The lowering of reimbursement rates had little impact on patients' behaviour, most of the increase in copayments being made up for by supplementary insurance. Lastly, the global budget for hospitals had increasingly adverse effects owing to the weight of the historic budget bases. As these measures had little effect on the growth of health expenditure, health insurance deficits continued to worsen (Figure 7) and insurance contributions to rise. In the 1990s, the health insurance branch of the general scheme (CNAMTS) experienced a serious financial crisis, accumulating a total deficit close to FF 200 billion. The financing requirements of the various branches of the social security were first covered by cash advances from the Caisse des Dépôts et Consignations. This debt was consolidated in a parastatal body set up in 1996, the CADES, and another contribution, the cotisation pour le remboursement de la dette sociale (CRDS) was introduced to pay it off.

\section{The break introduced by the Juppé Plan}

21. Given the deterioration in the financial situation of the public health insurance funds, the authorities became aware that purely budgetary and macroeconomic mechanisms were insufficient, and that more ambitious reforms would be necessary to achieve greater microeconomic efficiency. They also became aware that, given the large amount spent on health care, a periodic public debate was needed to set the general thrust of health care policy. This led to the enactment of a series of ordinances in 1996, the socalled Juppé Plan, which reformed the system of health care and health insurance, coupled with a revision of the Constitution. 
Figure 7. General health insurance scheme

Annual balance in per cent of GDP

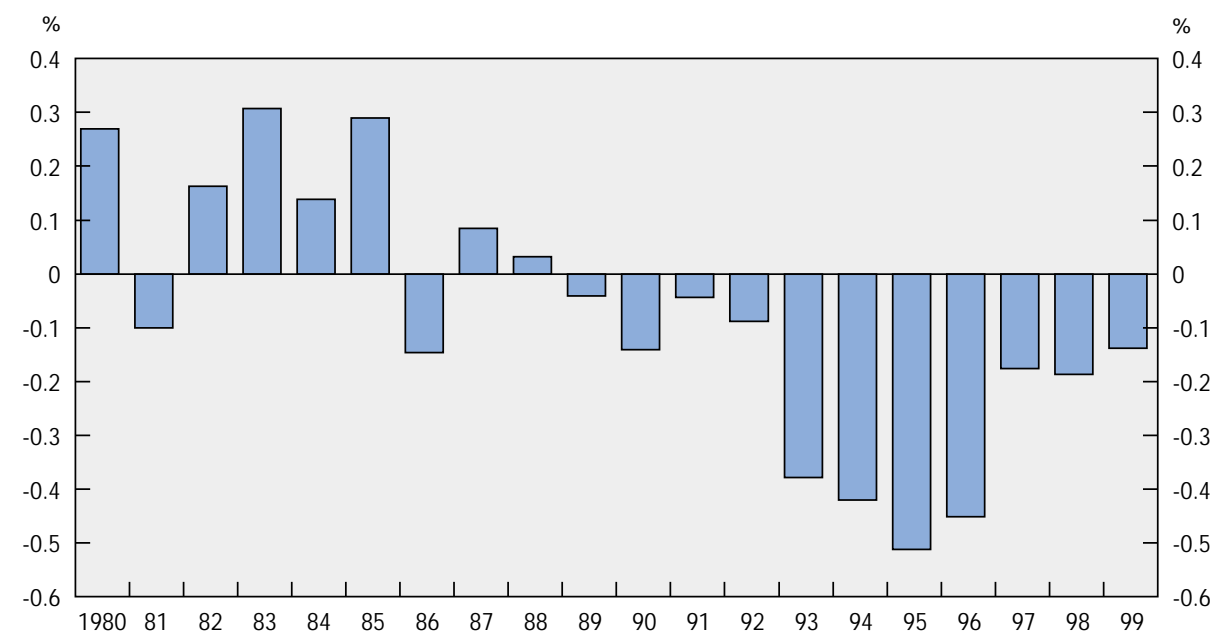

Source: Commission des Comptes of the Social Security

22. The Juppé Plan continued the macroeconomic approach but introduced important structural measures. Unlike previous reforms, it was not confined to increasing social contributions or co-payments but introduced wide-ranging budgetary reforms through amendments to the Constitution. Changes made to the way the health insurance funds operate, through a number of ordinances, were the most important since those of 1967. Now, Parliament adopts every year, as part of the law on the financing of social security, a national health spending objective (ONDAM) which sets targets to the spending and reimbursements made by the mandatory basic schemes (Table 3 ). The ONDAM comprises a spending target for ambulatory care (private fees, prescriptions, per diem sickness benefit), a target for public hospitals, a target for private clinics and a target for the medical-social sector (the elderly, maladjusted children, handicapped adults). The ONDAM is not a cap on reimbursements and thus does not have a compulsory character, since benefits are paid even if the target is exceeded. The aim is to take decisions and set priorities so that the government's financial objectives are achieved.

\section{Assessment of recent reforms}

23. Following the implementation of successive reforms, the growth of health care expenditure slowed during the second half of the 1990s. After having risen by 1 percentage point between 1990 and 1995, the share of health spending in GDP fell slightly between 1995 and 1998. Although this trend is less pronounced than in other European countries (Denmark, the Netherlands, Sweden, Finland and Italy), it marks a reversal of developments in previous years. The introduction of quantified national targets -- notably for clinics, biologists and independent nurses -- in 1991-92, the first agreements with pharmaceutical laboratories in 1993, and the Juppé reform in 1996 thus succeeded in curbing the rising trend of health spending. However, this "pause" should not automatically be read as a lasting change in trend. Earlier plans to reform health insurance were also followed by a slowdown of expenditure, but then expenditure picked up again at the previous rate. 
Table 3. Health insurance spending targets and outturns

Annual percentage changes

\begin{tabular}{|c|c|c|c|c|c|c|c|c|c|c|}
\hline & \multicolumn{3}{|c|}{1997} & \multicolumn{3}{|c|}{1998} & \multicolumn{3}{|c|}{1999} & \multirow{2}{*}{$\begin{array}{c}2000 \\
\text { Target }\end{array}$} \\
\hline & Target & Result & Diff. & Target & Result & Diff. & Target & Forecast & Diff. & \\
\hline Ambulatory care & 2.0 & 1.8 & -0.2 & 2.4 & 5.8 & +3.4 & -0.5 & 4.2 & +4.7 & 2.0 \\
\hline \multicolumn{11}{|l|}{ Disbursements to } \\
\hline - public hospitals & -0.1 & 0.2 & +0.3 & 2.0 & 1.7 & -0.3 & 2.6 & 2.4 & -0.2 & 2.4 \\
\hline - medical/social sector & 2.3 & 2.8 & +0.5 & 2.7 & 5.8 & +3.1 & 2.1 & 4.0 & +1.9 & 4.9 \\
\hline - private clinics & 9.2 & 5.9 & -3.0 & 1.7 & 3.0 & +1.3 & -1.8 & 3.3 & +5.3 & 2.2 \\
\hline ONDAM & 1.7 & 1.5 & -0.7 & 2.3 & 4.0 & +1.7 & 1.0 & 3.1 & +2.1 & 2.4 \\
\hline
\end{tabular}

Source: Cours des comptes and Assemblée Nationale. 
24. In fact, reimbursements for health treatment grew by nearly 4 per cent in 1998 and by 3 per cent in 1999, with inflation at under 1 per cent. Admittedly, this was partly due to cyclical factors. The purchasing power of households grew strongly during this period, and econometric estimates show a relatively high elasticity of health care consumption with respect to disposable income ${ }^{8}$ (Figure 8). Nevertheless, purchasing power gains do not explain entirely the strength of health care consumption in 1998-99. The loss of credibility of the financial sanctions put in place by recent reforms also seems to have been a factor. Some provisions of the Juppé Plan have been called into question ${ }^{9}$. The application of across-the-board financial sanctions to private clinics and pharmaceutical laboratories has also run into legal difficulties ${ }^{10}$. Furthermore, the ONDAM set by Parliament has been exceeded for several years running despite reaction from the government. In the hospital area, budget discipline has been respected but little progress has been made in reorganising hospitals and in adapting them to changes in health care demand. The strikes in public hospitals show that spending is still not securely under control. Lastly, the fact that the health insurance scheme is back in balance ${ }^{11}$ is probably encouraging ambulatory care providers and consumers to revert to their previous habits of over-prescribing and over-consuming. It is, thus, possible that the effect of the 1996 ordinances and previous reforms is gradually wearing off and that the slowdown of expenditure in the second half of the 1990s was only temporary.

25. Several other factors will also contribute to the structural rise in health expenditure over the long term. One is the ageing of the population, as the generations that have been used to relatively easy access to health care reach an advanced age (Mahieu, 2000). The elderly will increasingly be people born after World War II, who have been relatively large consumers of health care. Due to the age structure of the population and increasing life expectancy, the number of people aged 75 and over -- i.e. those who are usually large consumers of dependency-related health care -- will increase from 4.2 million in 1990 to 6 million in $2020^{12}$. Furthermore, it is well established that a large proportion of health expenditure is concentrated on a small number of people, in particular the elderly and seriously ill. In 1995, these "big consumers" of health care represented 10 per cent of the population but accounted for 70 per cent of reimbursements (CREDES, 1999). Their average age was 51 (compared with an average age of 35 for the population as a whole) and a third of them were 65 and over. Given the demographic projections, the number of "big consumers", as well as their medical expenditure, will probably rise steeply in the next few years. For instance, the number of patients with Alzheimer's disease could, on the basis of simple

8. Simple econometric regressions suggest an elasticity of health care consumption with respect to income of over 1. However, this finding should be treated with caution since it is very difficult to measure the true elasticity of health care consumption with respect to income, other things being equal. International studies suggest that this elasticity is close to 0.8 , once supply factors have been taken into account (Gerdtham and Jönsson, 1995).

9. The provisions of the Juppé Plan regulating independent medical practice were substantially cut by the Conseil d'État and the Constitutional Court, following appeals and referral by Parliament. In particular, an agreement of 1997 whereby doctors would be obliged to refund amounts in excess of the target for ambulatory care was voided in 1998, and there was no mechanism for controlling such expenditure in 1998 and 1999. In 1997, general practitioners respected their target but specialists did not. In 1998, the overrun was due in large part to ambulatory care, and especially to drug prescriptions by general practitioners.

10. The decision by the government in 1999 to lower the prices of private clinics by 1.95 per cent was cancelled by both the Conseil d'État and the Constitutional Court.

11. Admittedly, the government projects that the deficit on the health branch of the social security will be significantly reduced in 2000 . However, it should not be concluded from this that the financial situation is now sound. Revenue was boosted in 1998 and 1999 by a steep increase in job creation and thus in the wage bill -- the main component of the base on which social insurance contributions are calculated -- while expenditure benefited from the slowing of inflation. The quasi-balance projected for 2000 , at the peak of the cycle, could thus very well mask a structural deficit.

12. INSEE, Projections de la population, INSEE Résultats no. 361-362-363. 
assumptions, rise steeply in the medium term (DREES, 1999). Other factors will push up health expenditure, though their impact is difficult to quantify. Technological progress is an important factor in driving up expenditure (Newhouse, 1992) since it creates a demand for improved quality of life and increased life expectancy. The generosity of the French system, and especially universal health insurance, is also likely to push up expenditure, even though a better balance between ambulatory care and hospital care can be expected.

Figure 8. Relative trend of health care expenditure and national income Constant prices

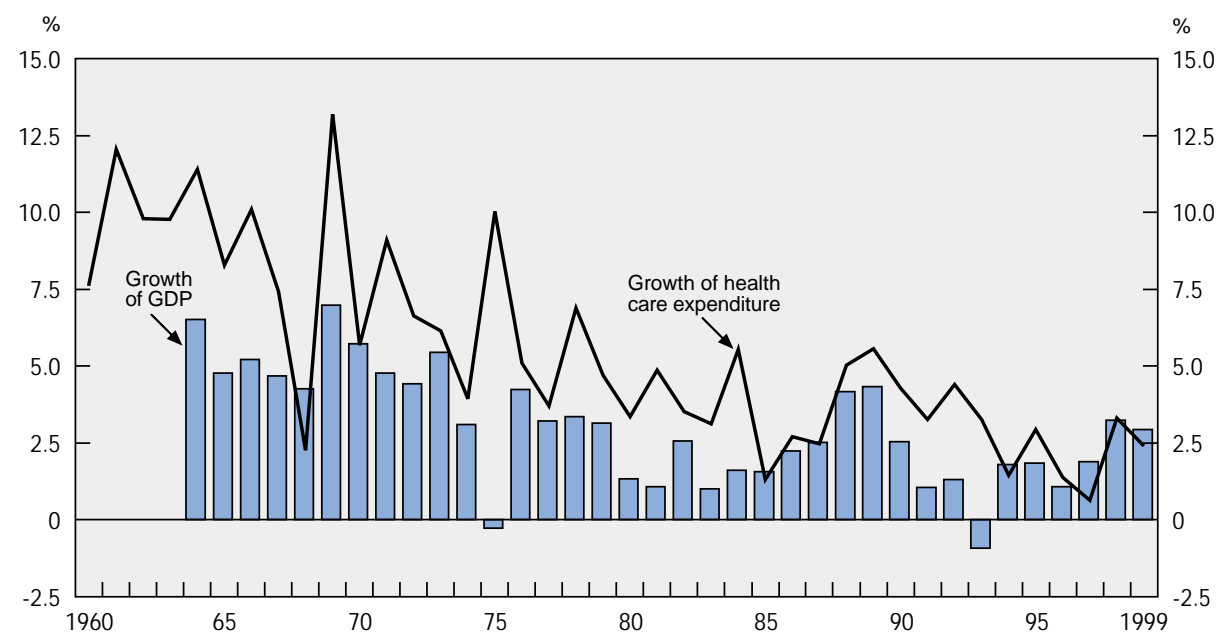

Source: INSEE.

26. Health sector reform thus remains a priority. French experience shows that purely macroeconomic measures are insufficient. Reducing the rate of reimbursement of health expenditure -- the customary method in France -- has usually not had the anticipated effect since supplementary insurance and the mutuelles have made good the difference. The other thrust of recent reforms in France -- financial constraints on health care providers --- has encountered fierce resistance from health care professionals, who have refused to be made accountable for the community's over-spending and have won their case in the courts. In contrast, international experience suggests that microeconomic reforms focusing on incentives to change agents' behaviour are indispensable tools in improving the functioning of the health care system (see Box 1 above). Consumption and prescription behaviour can be influenced by changing incentive mechanisms, though precautions need to be taken to ensure that this does not produce undesirable side effects. The microeconomic reforms implemented in other countries have been informed by basic principles of health care economics (see Box 5). 


\section{Box 5. Health care economics}

Understanding what works and does not work in the health care sector is a major challenge for most economists. This is because this sector does not operate like a normal economic sector. First, equity of access is of more concern than for most other goods and services. Secondly, health care is one of the areas where market mechanism alone cannot guarantee a pattern of resource allocation which is considered by the authorities to be optimal. According to standard public economics textbooks, this is due to problems known as information asymmetry, moral hazard and adverse selection. Lacking the information necessary to make informed decisions, patients delegate most treatment decisions to medical service providers. Information asymmetry thus makes the demand curve dependent on the supply curve. In this situation, if service providers are paid on a fee-for -service basis, and hence have an incentive to provide as much services as possible, the problem of demand inducement occurs. Moral hazard arises when people with generous health insurance spend more on medical care than necessary, and in particular more than people without health insurance. Because some people are healthier than others, sometimes from birth, private insurance markets are unable to guarantee access to health care in an equitable manner in the absence of government regulation. Private insurers tend to "cream off" the most healthy people (adverse selection), and leave the rest for the government (Hsiao, 2000). On the other extreme, provision of health care by the public sector is prone to government failure. Too much or too little may be spent on health care and public providers have earned a reputation for a lack of responsiveness to consumers. Health care policies thus have to navigate between the risks of both market failure and government failure.

A considerable literature has emerged regarding the design of appropriate health insurance schemes that would promote quality of services and cost effectiveness. Such a research is very relevant for France, because the government has taken responsibility for the management of the health insurance scheme. Studies in this area generally conclude that health insurance schemes are threatened by two major risks : moral hazard and demand inducement (Cutler and Zeckauser, 1999). In France, where the combined reimbursements by social security and private "mutuelles" can be very generous, the risk of moral hazard needs to be taken seriously. Without adequate safeguards, demand for medical consumption can be higher than necessary. As well, most physicians are paid on a fee-for-service basis and may therefore induce unnecessary demand to boost their incomes. In other words, in a generous health insurance system with a fee-for-service payment, patients and physicians have a joint interest in maximising the amount of reimbursement extracted from the insurer.

For authorities in charge of public health insurance schemes, the main challenge is therefore to limit these risks. The literature suggests that demand-side measures have some impact (Newhouse, 1993). Traditionally, insurers have tried to contain the risk of moral hazard by shifting part of the cost to the insured. This can take the form of higher co-payments, coverage limits or deductibles. However, if demand for ambulatory care is partly elastic to cost-sharing, this is not the case for impatient care. In addition, cost-sharing has a negative equity implication as its impact would be greater the lower patients' income is. This leaves the supply side to work on to contain the risks associated with heath insurance. Governments and insurers have developed a range of tools to regulate the behaviour of providers in the health field. One key parameter is remuneration. On the one hand, doctors paid by fixed salaries will have no incentive to induce demand, but they will also have less incentive to see the patient quickly. Spending can be controlled by setting global budgets but responsiveness and quality as perceived by the patient may suffer. On the other hand, doctors paid through fee-for-service will seek to maximise their income, subject to their leisure constraint. This will certainly lead to more responsiveness, but also to increased spending and sometimes waste. Similar trade offs exist in financing hospitals, between global budgets and fee-for-service. More recently, schemes such as Diagnostic Related Group (DRG) -- indemnity payments that are depending upon a mix of diagnostic and treatment, have been implemented, firstly in the United States and in a number of countries. In France, they have started to play a limited role in monitoring budget allocations.

Besides payment systems, several mechanisms can be implemented in order to reduce information asymmetries between providers of care and those paying them. These include peer review systems, publishing provider "performance indicators" for consumers and purchasers and introducing tighter contracts for providers, and a closer association between providers and payers through contracts and alliances, or even full integration. Managed care is a good example of this, and it is therefore not surprising that HMOs have expanded relatively fast in the United States. In France, doctors have traditionally been reluctant to contract alliances with the public health insurance scheme and to accept peer review by a third party, and managing ambulatory care spending has therefore been a persistent problem. Public hospitals, on the other hand, can been seen as providers directly managed by the insurer, and it is therefore not surprising that with the help of global budgets substantial progress has been made in curbing their expenses. 


\section{What else can be done?}

\section{Define the responsibilities more precisely ...}

27. To a large extent, the difficulties involved in regulating health care reflect the fact that the roles of the three main actors in the system -- the health insurance funds, the representatives of health professionals and the State -- are not clearly defined. This situation has been described as one of "coirresponsibility"(Mougeot, 1999). Admittedly, the government has taken initiatives, but the role of the health insurance system in their implementation has been left vague, with a division of roles between the State and the CNAMTS that has led to a dilution of responsibilities. The insured have no direct control over the system and delegate their responsibilities to the social security, which in practice can only play a passive role. Trade unions, employers' representatives, the government, the elected representatives (who chair the boards of public hospitals), and health professionals, all exercise an influence over the system. Each group has its own objectives -- preserving jobs, increasing revenue, local development -- which are often at odds with the objective of running the health system efficiently. This dilution of responsibilities has not been conducive to the efficient implementation of the reforms however well designed.

28. With a view to allocating responsibilities more effectively, the law on the financing of the social security for 2000 introduced a new division of roles. The State will concern itself exclusively with the public and private hospital sector and drugs. In the public hospital sector, the government intervenes both directly and via newly-created regional hospitalisation agencies (ARHs) ${ }^{13}$, to determine the global budgets allocated to each hospital. The CNAMTS has the oversight of general ambulatory care, excluding drugs. It is thus responsible for containing the growth of fees of doctors in independent practice, and of other paramedical professions within the limits of the targets set by Parliament, and to report every four months to the government on actual expenditure in relation to targets. In the absence of agreements with professionals, it can propose remedial measures. While this new division of roles has the merit of clarifying institutional responsibilities, it will probably have little impact on the behaviour of health care consumers and providers. New institutional arrangements by themselves will not change the nature of the economic incentives that in the past encouraged over-consumption and over-prescription. Furthermore, such a division leads to a dual organisation of health care, with the hospital sector being treated in isolation from drugs, whereas a dynamic view of health care, which encompassed the effects of medical progress, should make it possible to replace major hospital treatment by lighter ambulatory care.

\section{... putting in place incentives to change behaviour ...}

\section{Institutional rigidities in the public hospital sector}

29. The hospital sector is characterised by marked institutional rigidities. Whereas to a large extent private clinics come under private law -- and, in a way, are like businesses -- hospitals are run more like public administrations. Private clinics respond rapidly to changes in financial and economic incentives,

13. The ARHs are streamlined decentralised structures which co-ordinate the services of the regional health insurance funds in the hospital sector and the State regional health and social services. At first, they had had financial responsibilities and overall oversight for the public hospital sector. They are in charge not only of allocating global budgets to hospitals but also of ensuring that their objectives and programmes are in line with the directives of the regional health conferences and with regional health organisation plans. They can, in principle, behave like "purchasers" of health care, like district authorities in the United Kingdom, but their limited autonomy vis-à-vis other institutional actors prevents them from playing this role in an active way. 
and underwent sweeping reorganisation during the $1990 \mathrm{~s}^{14}$. In contrast, in public hospitals, a set of administrative rules constrains decision-making, making it difficult to take optimal decisions.

30. The first factor of rigidity is that the conditions of service of hospital staff are governed by general rules set for the entire civil service, including those that apply to recruitment, redundancies, promotion and wage-setting. Furthermore, mobility between hospitals is particularly low. Hospital doctors are appointed directly by the ministry to a particular hospital and specialisation, which in effect makes it difficult to move them in the event of a reorganisation. A second element of institutional rigidity is the fact that hospital boards are chaired by the local mayor. As a hospital is usually the main provider of jobs in the area in which it is situated, local authorities have a direct interest in keeping it there. Thirdly, the accounting procedures used by hospitals have shortcomings. While hospitals enjoy certain derogations from public accounting, such as the right to make depreciation allowances, their accounting procedures do not give them an exact picture of their activity from the point of view of assets. At the central level, it is difficult to obtain a precise picture even of the land area occupied by hospitals in France.

\section{Inappropriate financial incentives}

31. The financial incentives for health care institutions are inappropriate. Public hospitals receive global budgets, which, to a large extent, are still calculated on the basis of past levels of expenditure. It is still very difficult to relate these budgets to actual medical activity, as the tools for doing so can only be introduced gradually. There is little incentive to reward performance in a public hospital, and the professional assessment of doctors is done mainly on the basis of their research activity. Private clinics operate on a fee-for-service basis, but the fee schedules are out-of-date. The price structure is still an administered one and lags behind gains in productivity ${ }^{15}$. This allows certain private providers to continue to earn high profits in areas where progress has been made in recent years, such as cardiosurgery, digestive endoscopy, and ophthalmology. Nothing was changed by the application of national budget caps to private clinics from 1993. Admittedly, this meant that fee increases had to be kept within the limits of those caps, but this new macroeconomic pressure only encouraged clinics to specialise in the most lucrative care in order to offset the tighter control over volume. Whereas previously private clinics could develop their activity whenever costs were below controlled prices, it is now in their interest to specialise in areas where relative margins are the highest.

32. The diversity of incentives has resulted in institutions specialising in particular types of care. Public hospitals have a virtual monopoly of emergency treatment and high-level research, and of psychiatric care due to their institutional prerogatives; also, in practice it is they who deal with elderly or socially-disadvantaged patients. The public sector also handles the bulk of major operations as well as lifethreatening conditions. Private clinics are often smaller and handle the bulk of minor surgery, for which their market share can be as high as 80 per cent, especially in the area of digestive diseases, endoscopies and eye surgery (Mouquet et al., 1999). The French health care system is thus a blend of an entirely public system like the British NHS, and a private sector, which operates on market principles as in the United States. This can lead to creaming-off, with private clinics implicitly selecting their patients. It is, thus, frequent for private-clinic patients with complications or life-threatening conditions to be transferred to

14. Private clinics are very flexible: between 1992 and 1998, a total of 320 reorganisations were implemented, affecting 700 clinics.

15. For example, a splenectomy is a complex operation usually done in an emergency and priced at FF 1570 including 20 days post-operative care, whereas a full coloscopy, four of which can be done in the same day, is priced at FF 1000 . A general anaesthetic is priced at FF 300 whereas an echocardiography costs FF 600 (Cour des comptes, 1998). Clearly, it is in the interest of the most efficient clinics to avoid doing splenectomies and general anaesthetics and to do coloscopies and echocardiographies instead. 
public hospitals. The financial distortions in the system have resulted in a segmentation of supply by type of care but without any price competition. Consideration should therefore be given to the introduction of competitive mechanisms with a view to making the functioning of this market more efficient.

\section{... which could be offset by shadow price competition}

33. The introduction of market mechanisms requires that medical services compete on price. But it is particularly difficult to set prices that encourage the provision of high-quality care while at the same time promote efficiency, since health care institutions are also involved in the provision of public goods such as teaching and research. The idea of paying for health care on the basis of diagnosis-related groups (DRG) is starting to gain ground in France. The fact of reimbursing hospital stays on a DRG basis is tantamount to financing public hospitals on the basis of their actual activity, allowing for the structure of the services they provide, rather than on the basis of historic levels of expenditure. This will require a number of adjustments however. International studies on the subject have opened up some interesting avenues, drawing particularly on the US experience. The US approach consists in putting in place a number of offsetting mechanisms, mainly to cover the costs of teaching and research and exceptional stays. In France, the first task was to transpose this adjustment to a French context, notably by carrying out a national study of teaching and research costs (Pouvourville, 1997). The fact that public hospitals also have to cater for more disadvantaged social groups can also mean longer stays and more treatment because illnesses are treated later than for other groups. Studies show that the cost difference between disadvantaged and non-disadvantaged patients for identical homogenous groups of patients can be as high as 30 per cent (Mathy and Bensadon, 2000).

34. Direct implementation of DRG payments in the current context would penalise these nonquantified quality elements or could lead to cream-skimming, encouraging public hospitals to select their patients. In the United States, for example, the legislator recently increased payments to cover the share of exceptional costs so as to enable public hospitals to continue to treat the uninsured via cross-subsidisation. Despite the aforementioned technical difficulties, however, this seems the most promising avenue of development.

\section{Alternative systems are possible in the ambulatory care sector}

35. All ambulatory care is on a fee-for-service basis ${ }^{16}$. The pricing system rests on a fee schedule established in 1972. Progressive revision, patterned on the work of Hsiao at the Harvard School of Public Health and commenced some years ago, is not yet complete (Aliès-Patin et al., 2000). The aim is to establish a common classification of medical services ${ }^{17}$ to replace the present dual system (one fee schedule for hospital services, the other for ambulatory care).

36. In an endeavour to curb consumption of ambulatory care, the authorities have so far applied cuts in reimbursement rates. But these have had little effect. For most people with health insurance the cuts are offset by reimbursements from supplementary insurance, while the segments of the population on the social fringe turn to hospital care which is provided free of charge but at greater total cost to the community. Finally, for the people benefiting from CMU the previous cuts in reimbursement are no longer applicable. In the absence of co-payment, there is little restriction on the consumption of health care. Most individuals can consult a general practitioner or specialist as often as they want without any

16. Consultation fees in constant francs rose by 22 per cent for general practitioners and 12 per cent for specialists between 1980 and 1996.

17. La Nomenclature Générale des Actes Professionnels (NGAP). 
pecuniary consequences. It therefore seems necessary to give thought to the "moral hazard" inherent in the system. Any insurance plan that lacks adequate safeguards will encourage individuals to alter their behaviour and ask the insurer to bear the consequences of decisions they would probably not have made had there been no insurance. The traditional solution is to pass on a proportion of the cost to the insured party by way of co-payment. Another way to reduce the moral hazard is to set up a system of referral or "gate-keeping" by general practitioners, as in the United Kingdom. But existing studies show that the referring practitioner system itself generates extra costs, since a large share of consultations simply result in referral to a specialist (Kirman, 2000). The referral system is extensively used in the United States in the context of "managed care", but it introduces a loss of freedom in the choice of health provider, since the patient has to choose from a list of approved providers.

37. The "médecin référent" option proposed to practitioners in France is a first step toward this type of co-ordinated system. But the financial incentives are small, since the reimbursement rates remain the same for patients, who are simply exempted from putting the money up front. The practitioner receives a few additional payments for taking on a patient, but the medical profession's reluctance has so far prevented the introduction of capitation payment as such, even on a partial basis. The doctor has to undertake to prescribe a certain proportion of generic drugs, and patients lose the benefits of this system if they decide to consult specialists directly. Not surprisingly, few doctors are in this system, only about 10 per cent of general practitioners having joined in 1999.

\section{Improved evaluation of the medical benefit of pharmaceuticals and development of generics}

38. Pharmaceutical supply is regulated (Jacobzone, 1998) but demand is not, since co-payments are neutralised for a large share of the population. This is reflected in per capita consumption of pharmaceuticals: in 1996, France had the second highest level of drug consumption in the world after Japan and the highest in Europe (Figure 9). Supply is regulated through incentives offered to drug companies and pharmacists. An agreement was concluded between the government ${ }^{18}$ and the pharmaceuticals industry in July 1999 covering the period 1999-2000, with a strong emphasis on administrative control and quantified targets for consumption in each therapeutic class. These targets were set so as to be consistent with the national targets for health insurance expenditure (ONDAM). The agreement has opened the way to arrangements between individual drug companies and the government. Each arrangement contains undertakings by the signatory laboratory as to the level of sales, refunds due in the event of target overruns, reduction of promotional expenditure, development of generic drugs and the move to self-medication. However, a policy of this kind is likely to lead to a tightly administered management of pharmaceuticals supply with no possibility of allowing market mechanisms to operate.

18. Represented by the Comité Économique du Médicament, now renamed Comité Économique des Produits de Santé. This body comprises representatives of the social affairs and finance and industry ministries and the health insurance authorities. 
Figure 9. Per capita pharmaceutical spending and GDP In US\$, 1996 exchange rate

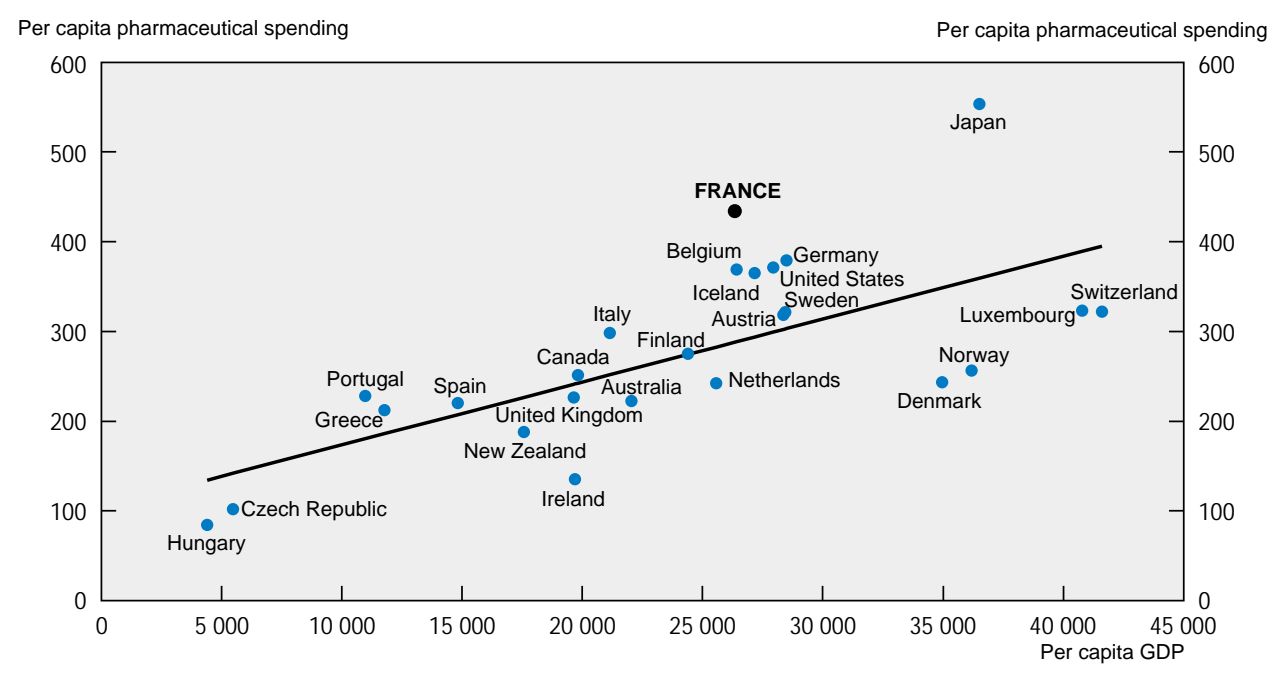

Source: OECD, National Accounts and Health Data 99.

39. An initial assessment of the medical benefit of marketed pharmaceuticals, covering about onefourth of the total market, was published in the summer of 1999. Nearly 15 per cent of the 1100 drugs examined were judged to be of insufficient medical benefit. However, these findings have had very little practical impact on cost reimbursement, and no decision has been taken as regards follow-up action. In many OECD countries, over the recent period, such products have been removed from the list of reimbursable medicines. France seems unwilling to use this approach and only a few slight price cuts have been imposed as yet. It is true that structural reforms of the drugs industry are liable to conflict with local development objectives, given the location of the pharmaceutical laboratories whose products might be taken off the list.

40. Incentives have been introduced to develop the generic drug market. Generic medicines accounted for about 8 per cent of drug sales by volume at end-1999, compared with nearly 70 per cent in the United Kingdom. French pharmacists are now entitled to an increased mark-up on generic medicines, but in return have to commit themselves to achieving a certain rate of substitution between brand and generic drugs, with a slight reduction of their remuneration if those rates are not achieved. However, there is no mechanism at the level of prescribers and consumers to encourage use of the less costly medicines, apart from the médecin référent system. Although it takes time to generate a supply of generic drugs and to establish the conditions for operation of a generics market, France has fallen way behind the countries that have applied policies of case-related reference pricing. To date the government has ruled out this possibility, although it has been developed in many European countries over the recent period. Admittedly, reference prices may be difficult to apply and suppliers may try to get around them. Also, the authorities fear possible anti-redistributive effects, certain studies showing that in France such a move might result in higher health costs for persons without supplementary insurance. But this does not allow for the switch to less expensive products. The importance of the policies being applied elsewhere is that they influence personal behaviour and shift consumption to similar but less costly products, while protecting consumer well-being. 


\section{... improve the management of health insurance funds ...}

41. The CNAMTS's ability to perform an active role as the national paying agency has remained limited owing to its institutional environment. First, it is not responsible for the entire system, the State being in charge of the hospital and prescription medicine sectors. Second, it has only relative authority over all the regional and departmental funds, which remain distinct legal entities with their own governing boards. Furthermore, the CNAMTS is not empowered to withhold approval of a health service provider, and therefore has to accept all reimbursements whatever the conditions of local provision. The CNAMTS strategic plan published in 1999 (Annex I) mentions the procedures for a periodic reassessment of the credentials of the medical profession. This would constitute an upheaval in the modes of medical practice in France, and the measures leading to refusal of accreditation are very tricky to implement.

42. The CNAMTS's action is hampered by a very cumbersome set of rules, with nearly 15000 statutory texts. Despite the introduction of CMU, the health insurance funds must continue to do a great deal of checking in order to decide how entitlements to the basic scheme are to be awarded. Certain procedures, such as those concerning agreement to provide cover prior to treatment, are very resourceintensive and of uncertain economic benefit. Thus, according to certain calculations, administrative management accounts for over 10 per cent ${ }^{19}$ of the expenditure actually managed by the funds. The bulk of the management cost is attributable to the refund of endless small sums paid directly to doctors by their patients. This contrasts with the system applying in some Canadian provinces where doctors are paid directly by the public insurance scheme, which permits substantial savings.

43. Despite the possibilities offered by computerisation, there are still 129 insurance offices in metropolitan France for the general scheme, with a combined staff of about $90000^{20}$. The conditions for restructuring insurance fund activity raise the same problems as those encountered in the case of public hospitals, notably local opposition to the closure of local health-insurance-fund offices. Restructuring of those offices is even more difficult to envisage in the present period, with the double pressure created by the introduction of CMU and expectations regarding the 35-hour week. Sporadic social unrest affected some of the offices in 1999 and long delays in reimbursement have been recorded, amounting to as much as six months in the Paris area.

\section{... and develop tools of evaluation and performance measurement}

44. The health insurance funds have facilities for evaluating and measuring the performance of health care providers. They have a medical service comprising 11000 doctors in all, who are required to monitor the activity of independent practitioners. The service is developing various surveys for this purpose. As yet, however, the funds have only limited authority as regards standards of care quality.

45. At hospital level, quality certification procedures have been developed as from the late 1990s. Care quality evaluation was made compulsory in 1991 and a special research fund was set up for the purpose. In 1990 the Agence Nationale pour le Développement de l'Évaluation Médicale (ANDEM) was established. Since the Juppé reform this agency, renamed Agence Nationale d'Accréditation et

19. Ratio of administrative management expenditure plus medical verification, i.e. FF 32.5 billion, to benefits paid in metropolitan France excluding payments to public hospitals, i.e. FF 310 billion in 1999 (Commission des comptes de la Sécurité sociale). The ratio would be reduced to 5.8 per cent by including hospital grants, but excluding the contribution of State services to hospital management.

20. This figure should be treated with caution. The Cour des comptes has pointed out that it is difficult to gauge exactly the number of staff actually employed in agencies that are subsidiary to the national funds (Cour des comptes, 1999b). 
d'Évaluation en Santé, has seen its activities and resources enlarged. It is now, after AHCRQ (Agency for Health Care Research and Quality) in the United States, one of the leading agencies of this type in the world. It takes part in the development of evidence-based medicine by way of close contacts with expert panels and medical journals. It also evaluates medical technologies and will soon take over the process of accreditation of hospital services. The Références médicales opposables (RMO), an official negative list of medical practices, have contributed to these developments. But in spite of these innovations, which are part of the modernisation of France's health care system, no way has been found to link performance evaluation with economic incentives, so as to make it possible to "buy" quality.

\section{Conclusion and recommendations}

46. The French health care system functions within a framework of macroeconomic regulatory mechanisms, of which the only one that appears to be effective is budgetary control of the public hospitals. But stabilisation of hospital expenditure is fragile, since it is achieved under the pressure of external budgetary constraints rather than on the basis of internal restructuring. Public hospitals are subjected to budgetary rules and thus have no incentive to optimise their services and their operating costs. The challenge here is to design, in a context of global budgets, reforms that will help the hospital sector to change and adapt to the needs of society. There is no miracle solution to the problem of the public hospital. What is needed is a reform package encompassing the remuneration of hospital services, the institutional framework, hospital staff regulations, and modes of governance.

- The method of remunerating hospital services should be reformed so as to establish an environment that encourages hospitals to provide high-quality services at optimal cost. For this purpose, diagnosis-related payment, with the necessary adjustments, could be introduced into hospital financing by the regional hospitalisation agencies (ARH).

- The role of the ARH should therefore be expanded and these agencies should be made more autonomous to enable them to act as care purchasers and to obtain affordable high-quality care for patients. Tendering could be introduced for the purchase of standardised care in order to promote competition between suppliers on the basis of a harmonised price structure.

- A new method of remuneration will have an impact only if the hospitals themselves acquire more autonomy of management, allowing them to change. Greater flexibility of management might be achieved if hospitals were to become autonomous public corporations with a status based on that of the Établissements Publics à Caractère Industriel et Commercial (EPIC), like other public services such the postal system (La Poste) and the SNCF (French railways). The tools of economic management also need to be modernised, notably cost accounting, valuation of invested capital and property in the annual accounts, and depreciation of fixed assets.

- Similarly, new personnel management methods are necessary to increase staff mobility between hospitals and to permit more flexible work organisation. Most importantly, there is a need for new modes of assigning medical staff to establishments that give the hospitals themselves more room for manoeuvre. The recent example of the postal system shows that it is possible in France to make extensive changes in a public service with a high use of labour and to maintain a guarantee of total employment without commitment to any particular establishment. Performance assessment of management staff and hospital doctors also needs to be strengthened so as to improve career management. Lastly, the inevitable introduction of the 35-hour week provides an opportunity to reorganise work in hospitals, with annualised work time arrangements and new methods of counting work hours. To facilitate mobility, financial 
incentives should be offered to doctors so as to put an end to private patient treatment and private beds in public hospitals.

- A new mode of governance is needed in order to clarify the respective roles of elected members of city councils, central government and hospital personnel. Hospital boards should doubtless be given increased powers, though this should also imply greater financial accountability and greater transparency in terms of medical performance. Boards opposed to restructuring measures proposed by the ARH should, for example, be required to present alternative strategies and specify the necessary financing, as is done in relations between the SNCF and the regional councils.

47. Unlike the case with public hospitals, which are subjected to strict budgetary rules, independent medical practice and the activity of private clinics were until recently subject to only limited regulation since the financial sanctions prescribed by the Juppé Plan were disallowed by the courts. Similarly, demand for ambulatory medicine is subject to only limited restraints, given that the supplementary reimbursements by mutuelles offset in large part co-payments by their members, and CMU allows this medicine free of charge to low-income households. A number of changes might be made here.

- In creating the illusion that medical care comes free of charge, reimbursements by supplementary insurance schemes generate negative externalities. Since a very large proportion of their expenditure is refunded, insured persons tend to consume unreservedly without heed to the prices charged. Furthermore, the negative externalities generated by the basic scheme are not included in the calculation of the premiums for supplementary cover. Basic and supplementary insurers therefore need to engage in discussions with a view to devising more appropriate methods of financing health care, to redefining cover and to striking a better balance between prevention and curative care. These discussions could also address the definition of a basket of reimbursable care such as exists in the Netherlands or in the United States in Oregon's Medicaid system. Given the institutional features of the French health care, the introduction of such a basket should be considered with a view to facilitating the joint modernisation of basic and supplementary cover.

- Demand can also be regulated by means of screening access to certain specialists. The médecin référent system could be adjusted so that the referring general practitioner would screen access to the categories of specialists in which flagrant over-use of care provision had been found. Choice of the referring physician should remain free, but incentives should be given so as to discourage frequent changes (e.g. annual subscription system), thus permitting better monitoring of patients and continuity of care. It would also be helpful to create specific care networks between health care professionals and institutionalised referral systems.

- In order to change the microeconomic incentives for agents, it is also necessary to modify the system of payment of doctors, by revising the links between activity and remuneration, with joint mechanisms to lessen the inflationary effects of the current system of payment per service. There is need for a new payments nomenclature specifying individual medical services, together with a continuous process of adjustment of the structure of specialists' remuneration to incorporate the effects of technical progress.

- Social security could set up a call centre to help users to decide whether they should consult a doctor or not and, if so, to choose between a general practitioner and a specialist, which would prevent unnecessary consultations. 
- Given the demographic ageing of the physician population, a procedure of periodic reaccreditation could be introduced so as to ensure that doctors' skills remain at the required level, especially in those specialities subject to rapid technological change. Depending on the outcome of the re-accreditation assessment, mandatory further training or redeployment could be proposed.

- The impact of CMU on patient behaviour, and hence on social security expenditure, should be closely monitored. A periodic evaluation procedure should be implemented regularly and its findings presented to Parliament, as CMU may prove much more costly than expected. In addition, much uncertainty still surrounds the future behaviour of CMU beneficiaries following its introduction. Finally, pressure may be brought to bear on supplementary insurers so that they offer the same cover as CMU, which they do not do today.

48. As far as medicines are concerned, the process of reassessing the therapeutic value of drugs needs to be complemented by decisions on reimbursement policy in line with these findings. Drugs whose medical benefit is not proven should be taken off the list of reimbursable medicines. Administrative pricing of medicines should be avoided wherever possible. The freedom of public hospitals to negotiate prices of medicines and supplies in the context of tenders should be extended to private clinics, which should be allowed to recoup part of the gains generated by bargaining. Where administrative pricing cannot be avoided, continuous adjustment should be made to allow for technological progress. Finally, there needs to be more competition between pharmacies. New incentives are required in order to encourage the development of generic drugs. For instance, the reference price for a reimbursable drug could be the price of the generic drug where such drug exists. The market in over-the-counter drugs sold by a pharmacist should be developed; in particular, this would facilitate the revision of the list of reimbursable drugs.

49. With regard to management of the health insurance system, processing of the feuilles de soins (patients' claim forms) by a single paying agent, rather than CNAMTS plus supplementary insurer as at present, might be envisaged. Competition between supplementary insurers should be stimulated on a more transparent basis so as to facilitate comparison of their charges. A business plan for the CNAMTS, based on cost reduction targets, should be adopted. In parallel, increased computerisation of doctors' offices is desirable, both as an aid to prescription and to facilitate monitoring and audit of activity.

50. Finally, although some progress has been made recently, public health policy needs to be given greater prominence. In France too much weight is given to treatment of illnesses and not enough to their prevention. The different policies concerning the population's health are poorly co-ordinated and insufficient resources are allocated to prevention (discouragement of smoking, cancer screening, frequent complete medical check-ups, and so on). France could follow the example of other OECD countries -- like the Nordic countries, for instance -- and establish procedures to gauge the performance of expenditure on treatment, as compared with prevention, and to better evaluate all the policies that have an impact on the population's health. 


\section{ANNEX I}

\section{HEALTH INSURANCE REFORMS}

\section{Reform plans to date}

\section{Plans}

Plan Durafour (1975)

Plan Barre (1976)

Plan Veil (1977-78)

Plan Bérégovoy (1982-83)

1984

Plan Séguin (1986-87)

Plan Rocard-Evin (1990-91)

Plan Bianco (1991)

Plan Veil (1993)

Plan Juppé (1996) -Ordinances of 24 April and organic law of 22 July 1996

Aubry measures (1998)

Aubry measures (1999)

\section{Main reforms}

Ceiling on social insurance contributions removed; VAT on drugs lowered. Co-payment (ticket modérateur) increased.

Contributions increased and rate of refund on certain non-essential medicaments reduced

Introduction of the forfait hospitalier (the per diem fixed charge which the patient has to pay for a hospital stay), co-payment increased, contribution introduced on unemployment benefits.

Introduction of global budgets for hospitals

Some drugs (vitamins) no longer reimbursed, revision of the list of illnesses giving exemption from co-payments, scope of exemption from co-payments limited, exceptional contributions.

Some drugs (anti-asthenics) no longer reimbursed, introduction of the CSG, tax on pharmaceutical advertising.

Contributions based on wages and the forfait hospitalier raised, some drugs no longer reimbursed. Introduction of National Quantified Targets.

Implementation of mandatory medical guidelines (RMOs), rules laid down regarding the patient's medical file, the first price-volume regulation agreements concluded with pharmaceutical companies. Forfait hospitalier increased, co-payment reduced by 5 points. CSG increased.

Introduction of ONDAM (national health spending targets) and law on the financing of the social security. Personal medical record, care groups, computerisation, policy of penalising ambulatory doctors in the event of budget overruns. Parliamentary control introduced over the social security, supervisory agencies (ANAES), redeployment of hospitals, RDS levy and exceptional contribution for doctors.

Pharmacists allowed to replace drugs prescribed by doctors, by generics; incentives for médécins référents; computerisation of doctors' offices; care networks; VITALE card; shifting employee health insurance contribution to the CSG.

Hospitals managed by the State, ambulatory care by the CNAMTS. Regional hospitalisation agencies (ARH) responsible for relations with private hospital sector; diagnostic-related group payments encouraged; spending targets assigned to health insurance funds;

Source: Based on Ventelou (1999) and National Assembly (1999). 


\section{The 1996 Juppé Plan}

Objectives: Achieve financial balance by 1997 through limits on expenditure and exceptional tax revenue measures; improve efficiency, effectiveness and quality of health care through a series of structural measures.

Legal basis: A constitutional amendment gives Parliament legislative authority over health spending, via the law on the financing of the social security which is passed every year, like the budget law. The social partners continue to be involved in the management of the system but the key decisions are taken by Parliament and implemented by the government.

Macroeconomic regulation: Each year Parliament sets a national health spending target (ONDAM) based on revenue estimates and the national health goals defined by the National Health Conference. The fact that the national spending target is voted by Parliament means that the nation's elected representatives make the desired amount of healthcare spending explicit for the first time.

Hospitals: The main innovation in the hospital area is the creation of regional hospitalisation agencies (ARHs). The ARH are streamlined structures that deal with hospitals. They co-ordinate the regional offices of the social security, and the State regional health and social services. At first, they had financial responsibilities and overall oversight for the public health sector ${ }^{21}$. They are in charge not only of allocating global budgets to hospitals ${ }^{22}$ but also of ensuring that their objectives and work are in line with the directives of the regional health conferences and also with regional health plans. To a certain extent they can behave like "purchasers" of health care, like district authorities in the United Kingdom.

Ambulatory care: The targets voted by Parliament also apply to ambulatory sector spending. Rules were set in case of under- or over-spending. The role of mandatory medical guidelines (RMOs) was increased and a personal medical record (carnet de santé) enabling doctors to keep track of their patients' medical history more effectively and accurately was introduced. Subsidies were provided to help doctors computerise their offices to allow electronic transmission of claims forms (feuille de soins), and experiments were launched where the general practitioner plays a gate-keeper role; a policy of encouraging the use of generic drugs was launched, as well as costly early retirement measures for the medical profession.

Information tools: The 1996 plan introduced, on a general basis, tools for measuring the performance and productivity of each hospital by comparing their relative costs by diagnosis-related groups (DRGs). The information system fixes the value of the point of a composite indicator of activity (ISA) on the basis of data in the Programme de médicalisation des systèmes d'information (PMSI). The value is calculated in francs for each hospital and each region, and is a key element in decisions regarding budget allocations. The value of the scale used to compile the composite index is calculated from a cost analysis of a sample of hospitals (thirty hospitals throughout the country).

21. The law on the financing of the social security for 2000 extended their role to private clinics.

22. Except for the Île-de-France region, where the budget allocation for the Assistance Publique-Hôpitaux de Paris is set by ministerial decree. The Ministries of Social Affairs, Finance and the Interior sit on its governing board. In this region, the ARH oversees health planning (beds and equipment) but, in the budget area, its role is limited to other minor or peripheral public hospitals and to the private sector since the law on the financing of the social security for 2000 . 


\section{The CNAMTS's strategic plan}

In July 1999, the CNAMTS published a strategic plan proposing a number of reforms in the way it operates. This plan does not call into question the principle of solidarity between those in good health and the sick, with everybody contributing according to their income and receiving care according to their needs. Nor does it seek to replace the system of refunding patients by one of financing health care supply directly. Lastly, it does not call into question the principle of the patient's freedom to choose a practitioner, nor the doctor's freedom to prescribe. What it does stress is that this freedom must go hand in hand with the responsibility of each individual in the running of the system, so as to guarantee the quality of care, to ensure that needs are covered and that costs are kept under control.

The plan stems from a recognition that the CNAMTS has become a "passive payer" because the rules prevent it from being a selective buyer, choosing care according to quality, needs, utility and costs. The plan seeks to make the CNAMTS a more responsible and more thrifty buyer. It estimates possible savings after five years at FF 62 billion. Of the 35 measures proposed by the CNAMTS, the main ones are the following:

- Hospitals. The plan suggests that savings of FF 30 billion could be made by replacing the global budget by a system of payment on the basis of diagnosis-related groups (DRG). This figure was arrived at by comparing the costs of clinics and those of hospitals, after adjustment for the extra costs arising from the research and teaching activities of hospitals, and from the higher wage bill that results from hospital staff having civil servant status. It suggests that there is large scope for productivity gains in the hospital sector.

- The insured. The plan aims at involving the insured more closely by varying the rate of refund in return for the acceptance of certain constraints. The rate of refund will be higher for patients who sign up with a médécin référent and are part of a health care group (the rate of refund is ten points higher); conversely, for patients who refuse the personal medical record (carnet de santé), the rate of refund is ten points lower).

- Doctors and health professions. The plan calls into question the payment by the CNAMTS of the social contributions of all doctors -- at a cost of FF 8 billion a year. This arrangement had been introduced in 1960, at a time when there was a shortage of doctors. The plan proposes to replace it by a subsidy, the amount of which would be capped and vary according to the density of doctors and certain other conditions (continuity of care, prescription of generic drugs, electronic transmission of claims forms). The plan also provides for a system of collective regulation, with doctors having to reimburse budget overruns.

- Drugs. Drugs would be reimbursed on the basis of the cheapest drug in the given therapeutic class. The charges for certain forms of treatment (chemotherapy, dialysis) would be reviewed and hydrotherapy would be refunded at a lower rate.

Most of the proposals in the strategic plan require decisions by the government and legislation. For the moment, the authorities have not decided to implement them. 


\section{GLOSSARY OF ACRONYMS}

ACOSS Agence centrale des organismes de Sécurité sociale

AHCRQ Agency for health care research and quality

ARH Agence régionale d'hospitalisation

CADES Caisse d'amortissement de la dette sociale

CANAM Caisse nationale d'assurance maladie des travailleurs indépendants et artisans

CMU Couverture médicale universelle

CNAVTS Caisse nationale d'assurance vieillesse des travailleurs salariés

CNMATS Caisse nationale d'assurance maladie des travailleurs salariés

CRDS Cotisation pour le remboursement de la dette sociale

DRG Diagnosis-related group

EPIC Établissement public industriel et commercial

LFSS Loi de financement de la Sécurité sociale

NHS National Health Service

ONDAM Objectif national de dépenses d'assurance-maladie

PMSI Programme de médicalisation des systèmes d'information

RMI Revenu mininum d'insertion

RMO Références médicales opposables

SNCF Société nationale des chemins de fer

URSSAF Union de recouvrement des cotisations de sécurité sociale et d'allocations familiales 


\section{BIBLIOGRAPHY}

Aliès-Patin A., G. Debeugny, F. von Lennep and H. Weissmann (2000) "Evaluation des ressources en vue de l'élaboration des honoraires des actes médicaux", CNAMTS, Division de la Nomenclature,

Contribution au $1^{\text {er }}$ colloque international des économistes français de la santé, L'Etat de la Réforme, February.

Amouyel et al., MONICA (1994), "Myocardial Infarction Case-Fatality, Gradient in Three French Regions: The Influence of Acute Coronary Care", International Journal of Epidemiology, 23, 4, pp. 700-709.

Assemblée nationale (1999), "Rapport fait au nom de la Commission des affaires culturelles, familiales et sociales sur le projet de loi de financement de la sécurité sociale pour 2000, Tome II, Assurance maladie et accidents du travail, par M. Evin, Député", Paris.

Beudaert, M. (1999), "Les honoraires des médecins généralistes entre 1985 et 1995", Direction de la recherche de l'évaluation et des statistiques, ministère de l'Emploi et de la Solidarité, Études et Résultats, No. 15, April.

Brocas, A. M. (1993), "La maîtrise des dépenses dans le secteur de la santé après la loi du 4 janvier 1993", Droit Social, March.

Bureau, D. and A. Plassart (1999), "Comment réguler les dépenses de santé ?", Les Cahiers Français, No. 292 (Emploi et Protection Sociale), Paris, July.

Caisse nationale d'assurance maladie (1999), "Des soins de qualité pour tous, refonder le système de soins", July.

Commissariat général du Plan (1993), "Santé 2010, Rapport Soubie", Éditions La Documentation Française, Paris.

Commissariat général du Plan, R. Soubie, J. L. Portos et C. Prieur (1994), "Livre blanc sur le système de santé et d'assurance maladie", Éditions La Documentation Française, Paris.

Commission des comptes de la Sécurité sociale (1999), "Les comptes de la Sécurité sociale", Paris, www.social.gouv.fr/htm/actu/secu/comptes/index-comptes.htm.

Cour des comptes (1997), "La Sécurité sociale", Les Éditions du Journal officiel.

Cour des comptes (1998), "La Sécurité sociale", Les Éditions du Journal officiel.

Cour des comptes (1999a), "La fonction publique de l'État", Les Éditions du Journal officiel.

Cour des comptes (1999b), "La Sécurité sociale", Les Éditions du Journal officiel. 
CREDES (1999), "Concentration des dépenses et grands consommateurs de soins médicaux", Bulletin d'information en économie de la santé, No. 20, July.

Cutler, D. M. and R. J. Zeckhauser (1999), The Anatomy of Health Insurance, NBER Working Paper 7176, Cambridge, MA., June.

Dab, W. (1997), "Crises de santé publique et crise de la santé publique", Revue française des affaires sociales, December.

Dormont, B. and C. Milcent (2000), "Coûts hospitaliers et tarification par pathologie, le cas de l'infarctus du myocarde aigu", Colloque international des économistes français de la santé.

Dourgnon, P. and M. Grignon (2000), Le tiers payant est-il inflationniste ?", Étude de l'inflation du tiers payant sur la dépense de santé, Report CREDES No. 1296, April.

DREES (1999), "Les personnes âgées dans les années 90", Études et Résultats, No. 40, Paris, November.

Gerdtham, U. and B. Jönsson(1997), "Les déterminants des dépenses de santé dans les pays de l'OCDE", in S. Jacobzone, Économie de la santé, Trajectoires du futur, INSEE Economica, Paris.

Gerdtham, U., B. Jönsson, M. MacFerlan and H. Oxley (1997), "Les déterminants des dépenses de santé dans les pays de l'OCDE", in Économie et Santé, Trajectoires du futur, INSEE Méthodes, pp. 11-24.

Girouard, N, and Y. Imai (2000), "The health care system in Poland", OECD Economics Department Working Paper No 257, Paris.

Hassenteufel, P. (1997), "Les médecins face à l'État, une comparaison européenne", Presses de Sciences Po.

Haut Comité de la Santé publique (1998), "La santé en France 1994-1998", Éditions La Documentation Française, Paris.

Hazera, J.-C. (2000), "Sommes-nous bien assurés ?", Problèmes Économiques, No. 2646, Paris, January, pp. 25-29.

Huber, M. (1999), "Health Expenditure Trends in OECD Countries, 1970-1997", Health Care Financing Review, 21, 2, 1-19, winter.

Hsiao, W. (2000), "What Should IMF Macroeconomists Know About Health Care Policy: A Primer", IMF Working Paper No. 00/136, Washington DC.

INSEE (1999), "Tableaux de l’économie française 1999-2000", Paris.

Inspection générale des affaires sociales/Inspection générale des finances (1996), Rapport sur la démographie médicale, by J. Choussat, Dr. A. C. Rousseau-Giral and G. Malabouche.

Inspection générale des affaires sociales (1997), Enquête sur les méthodes et outils de régulation du secteur médico-social, by M. Gagneux and J. L. Vidana.

Inspection générale des affaires sociales (1998), Survey on continuing medical training by Dr. A. C. Rousseau-Giral, P. Y. Bocquet, J. Guedj and J. Roigt. 
Institut d'étude des politiques de santé (2000), "Le choix des soins garantis par l'assurance maladie obligatoire problématique", I. Durand Zaleski, S. Hazard, D. Jolly and I. Vedel (ed), Médecine Sciences, Flammarion.

Jacobzone, S., I. Durand Zaleski and C. Chaix (1997), "Impact de la diffusion de l'innovation : le cas du traitement invasif de la pathologie coronarienne", in Dix ans d'avancées en économie de la santé, Actes des XIX ${ }^{\text {èmes }}$ journées des économistes de la santé française, John Libbey Eurotext.

Jacobzone, S. (1998), "Le rôle des prix dans la régulation du secteur pharmaceutique", Économie et Statistique, No. 312-131, pp. 35-54.

Jacobzone S. (2000), "Pharmaceutical policies in OECD countries: reconciling social and industrial goals", Labour Market and Social Policy Occcasional Papers, No. 40, OECD, Paris, http://www.oecd.org/els/papers/papers.htm.

Jacobzone, S., E. Cambois et J.-M. Robine (2000), "Is the health of older persons in OECD countries improving fast enough to compensate for population ageing?", OECD Economic Studies, No. 30, 2000/I, pp. 149-190.

Johanet, G. (1998), Sécurité sociale, l'échec et le défi, Le Seuil.

Kirman, A. (2000), "L’État de Santé de la Nation", Royal Economic Society Newsletter, January.

Koen, V. (2000), "Public expenditure reform: the health care system in the United Kingdom", OECD Economics Department Working Paper No 256.

L'Horty, Y., A. Quinet and F. Rupprecht (1997), "Expliquer la croissance des dépenses de santé : le rôle du niveau de vie et du progrès technique", Économie et Prévision, 129-130, pp. 255-265.

Mahieu, R. (2000), "Les déterminants des dépenses de santé : une approche macro-économique", Documents de travail No G2000/01, INSEE, Paris, January.

Mathy C. and M. Bensadon (2000), "Prendre en compte la précarité dans la comparaison des performances des établissements de santé: les leçons d'une étude", Mission PMSI, Direction des Hôpitaux, Centre de traitement de l'information du PMSI, Université de Jussieu, Colloque international des économistes français de la santé: L'Etat de la Réforme, February.

Mesrine, A. (1997), "Les inégalités de mortalité par milieu social restent fortes", La France, Portrait Social, INSEE.

Ministère de l'Emploi et de la Solidarité (1999), Annexes au projet de loi de financement de la Sécurité Sociale pour 2000, Annexe a, Données de la situation sanitaire et sociale de la population.

Morelle, A. (1996), "La défaite de la santé publique", Forum, Flammarion.

Mormiche, P. (1997), "Inégalités de santé et inéquité du système de soins", in S. Jacobzone, Économie de la santé, Trajectoires du futur, INSEE Méthodes/Economica, pp. 84-94.

Mossialos, E. (1997), "Citizens' view on health systems in the 15 Member states of the European Union", Health Economics, Vol. 6, 109-116. 
Mougeot, M. (1999), "Régulation du système de santé", Rapport du Conseil d'Analyse Économique, No. 13, Éditions La Documentation Française, Paris.

Mouquet, M. C., M. Joubert et L. Tudeau (1999), "Les pathologies prises en charge à l'hôpital, une spécialisation marquée entre établissements relevant du secteur public et du secteur privé".

Newhouse, J. P. (1992), "Medical Care Costs: How Much Welfare Loss ?", Journal of Economic Perspectives, 6, 3, pp. 3-23.

Newhouse, J. P. (1993), Free for All? Lessons from the RAND Health Insurance Experiment, The Insurance Experiment Group Coauthors. Harvard University Press.

OECD (1995), "New directions in health care policy", Paris.

Or, Z. (2000), "Determinants of Health Outcomes in Industrialised Countries: A Pooled, Cross-Country, Time-Series Analysis", OECD, Economic Studies, Nº 30, Paris, January, pp. 53-79.

Orosz, E. and A. Burns (2000), "Health care system in Hungary", OECD Economics Department Working Paper No 241.

Sénéquier, H. (1999), "La couverture médicale universelle", Regards sur l'actualité, Paris, November.

Van Doorslaer, E., A. Wagstaff, H. Bleichrodt et al. (1997), "Income-related inequalities in health: some international comparisons", Journal of Health Economics, 16, 1, 93-112.

Van Doorslaer, E., A. Wagstaff, F. Rutten (1993) Equity in the Finance and Delivery of Health Care, Oxford Medical Publications.

Ventelou, B. (1999), "Les dépenses de santé des Français : une maladie d'amour ?", Revue de l'OFCE, No. 71, Paris, October.

Vilain A. et X. Niel (1999), "Les inégalités régionales de densité médicale", DREES, Études et Résultats, No. 30, Paris, September.

Visco, I. (1999), "Welfare Systems, Ageing and Work: an OECD Perspective", Paper presented at the Conference "New Welfare and Social Security in Europe". 


\section{ECONOMICS DEPARTMENT \\ WORKING PAPERS}

268. Inward Investment and Technical Progress in the UK Manufacturing Sector (October 2000) Florence Hubert and Nigel Pain

267. Aggregate Growth: What have we Learned from Microeconomic Evidence? (October 2000) John Haltiwanger

266. Determinants of Long-term Growth: A Bayesian Averaging of Classical Estimates (BACE) Approach (October 2000) Gernot Doppelhofer, Ronald I. Miller and Xavier Sala-i-Martin

265. The Great Reversals: The Politics of Financial Development in the $20^{\text {th }}$ Century (October 2000) Raghuram G. Rajan and Luigi Zingales

264. Trade and Growth: Still Disagreement about the Relationship (October 2000) Robert Baldwin

263. Growth Effects of Education and Social Capital in the OECD Countries (October) Jonathan Temple

262. Human Capital in Growth Regressions: How Much Difference Does Data Quality Make? (October 2000) Angel de la Fuente and Rafael Doménech

261. Raising the Speed Limit: US Economic Growth in the Information Age (October 2000) Dale W. Jorgenson and Kevin J. Stiroh

260. Summary of an Informal Workshop on the Causes of Economic Growth (October 2000) Jonathan Temple

259. Knowledge, Technology and Economic Growth: Recent Evidence from OECD Countries (October 2000) Andrea Bassanini, Stefano Scarpetta and Ignazio Visco

258. Average Effective Tax Rates on Capital, Labour and Consumption (October 2000) David Carey and Harry Tchilinguirian

257. The Health Care System in Poland (September 2000) Nathalie Girouard and Yutaka Imai

256. Public Expenditure Reform: The Health Care Sector in the United Kingdom (August 2000) Vincent Koen

255. Regulatory Reform in Road Freight and Retail Distribution (August 2000) Olivier Boylaud

254. Regulation, Market Structure and Performance in Air Passenger Transportation (August 2000) Rauf Gonenc and Giuseppe Nicoletti

253. Policy Interdependence during Economic Transition: the Case of Slovakia 1999-2000 (June 2000) Joaquim Oliveira Martins and Tristan Price

252. E-Commerce: Impacts and Policy Challenges (June 2000) Jonathan Coppel 
251. The Implementation and the Effects of Regulatory Reform: Past Experience and Current Issues (June 2000) Rauf Gonenc, Maria Maher and Giuseppe Nicoletti

250. The Concept, Policy Use and Measurement of Structural Unemployment: Estimating a Time Varying NAIRU across 21 OECD Countries

(June 2000) Pete Richardson, Laurence Boone, Claude Giorno, Mara Meacci, David Rae and David Turner

249. Options for Reforming the Spanish Tax System

(June 2000) Isabelle Joumard and Aristomène Varoudakis

248. Economic Growth in the OECD Area: Recent Trends at the Aggregate and Sectoral Level (June 2000) Stefano Scarpetta, Andrea Bassanini, Dirk Pilat and Paul Schreyer

247. Economic Effects on the 1999 Turkish Earthquakes: an Interim Report (June 2000) Alexandra Bibbee, Rauf Gonenc, Scott Jacobs, Josef Konvitz and Robert Price

246. Policy Influences on Economic Growth in OECD Countries: an Evaluation of the Evidence (June 2000) Sanghoon Ahn and Philip Hemmings

245. The Tax System in the Czech Republic

(May 2000) Chiara Bronchi and Andrew Burns

244. The Tax System in Norway: Past Reforms and Future Challenges (May 2000) Paul van den Noord

243. A Changing Financial Environment and the Implications for Monetary Policy (May 2000) Paul Mylonas, Sebastian Schich, Gert Wehinger

242. Carbon Emission Leakages: a General Equilibrium View (May 2000) Jean-Marc Burniaux and Joaquim Oliveira Martins

241. The Healthcare System in Hungary (April 2000) Eva Orosz and Andrew Burns

240. Comparing Semi-Structural Methods to Estimate Unobserved Variables: the HPMV and Kalman Filters Approaches

(April 2000) Laurence Boone

239. New Issues in Public Debt Management: Government Surpluses in Several OECD Countries, the Common Currency in Europe and Rapidly Rising Debt in Japan (April 2000) Paul Mylonas, Sebastian Schich, Thorsteinn Thorgeirsson and Gert Wehinger

238. Regulation, Industry Structure and Performance in the Electricity Supply Industry (April 2000) Faye Steiner

237. Regulation, Market Structure and Performance in Telecommunications (April 2000) Olivier Boylaud and Giuseppe Nicoletti

236. Predicting the Evolution and Effects of the Asia Crisis from the OECD Perspective (April 2000) Pete Richardson, Ignazio Visco and Claude Giorno 